\title{
6 Die Zelle als gengesteuertes System
}

Die genetische Information der Pflanzenzelle ist in den DNA-Molekülen des Zellkerns (nucleäres Genom), der Plastiden (plastidäres Genom) und der Mitochondrien (mitochondriales Genom) niedergelegt. Die Genome der Plastiden und Mitochondrien leiten sich von Genomen prokaryotischer Organismen ab, die während der Evolution als Endosymbionten in die Eukaryotenzelle aufgenommen wurden, Endosymbiontentheorie. Diese Organellengenome, und die zugehörigen Mechanismen der Genexpression, zeichnen sich auch heute noch durch viele prokaryotische Merkmale aus. Andererseits unterscheiden sie sich von den heutigen Prokaryotengenomen z. B. dadurch, dass sie viele Gene an den Zellkern verloren haben, der in der Pflanzenzelle die dominierende Rolle bei der Replication und Transkription der genetischen Information übernommen hat und so viele Funktionen der Organellen steuert. Dieses Kapitel gibt einen Überblick über die Organisation der Genome und die komplexen Mechanismen der Informationsverarbeitung in der Pflanzenzelle, sowie die sich während der Evolution etablierten Abhängigkeitsverhältnisse und Kooperationen zwischen ihren drei genetischen Systemen. Unter Genexpression verstehen wir die Abfolge der molekularen Einzelschritte zwischen einem Gen und seinem reifen Genprodukt, z. B. einem funktionsfähigen Enzym. Dieser Begriff schließt also neben der Transkription (RNA-Synthese) auch die Reifungsprozesse auf der RNA-Ebene, die Translation (Proteinsynthese) und die Mechanismen der Proteinmodifikation und -(in)aktivierung ein. Die auf diesen verschiedenen Ebenen angreifende Regulation der Genexpression liefert die mechanistischen Grundlagen für die Steuerung der Zelldifferenzierung im vielzelligen Organismus und ist daher ein zentrales Thema der molekularen Pflanzenphysiologie.

\subsection{Das Gen - die Einheit der genetischen Information}

Von der Genetik ursprünglich als kleinste experimentell auflösbare Erbinformationseinheit definiert, bezeichnet der Begriff Gen heute den Bereich der DNA, in dem die in eine RNA umschreibbare Information codiert ist, und meistens auch die räumlich und funktionell dazugehörigen, nicht transkribierten Steuerabschnitte (Abbildung 6.1; Exkurs 6.1). Gene codieren ribosomale RNAs (rRNAs) und transfer-RNAs (tRNAs), die für die Proteinsynthese benötigt werden, oder ein Leseraster $(O R F=$ open reading frame $)$ für ein Protein, das über die Vermittlung einer messenger-RNA (mRNA) am Ribosom synthetisiert wird. Die Gesamtheit der in der Nachbarschaft zur genetischen Information liegenden Steuerabschnitte, cis-Ele- mente, inklusive der Bindungsstellen für die RNAPolymerase werden unter dem Begriff Promotor zusammengefasst. Die ebenfalls regulativ wirkenden, weiter entfernt liegenden cis-Elemente werden bei positiver Wirkung auf die Genexpression als enhancer, bei negativer Wirkung als silencer bezeichnet. Die cis-Signalstrukturen werden von transFaktoren erkannt, meistens Proteine, die woanders im Genom codiert sind.

Die Basensequenz eines Gens wird nach allgemeiner Übereinkunft so dargestellt, dass für den nicht-transkribierten DNA-Strang und die transkribierte RNA das 5'-Ende (normalerweise mit einem Phosphatrest) auf der linken Seite, und das 3' Ende (normalerweise mit einer $\mathrm{OH}-\mathrm{Gruppe}$ ) auf der rechten Seite liegen. Bei dieser Orientierung liegt der Ablesebeginn der genetischen Information auf der linken Seite. Auch die DNA-Replication er- 


\section{EXKURS 6.1: Wie identifiziert und isoliert man ein Gen?}

DNA lässt sich mit einfachen Methoden weitgehend intakt aus Pflanzenmaterial isolieren. Für weitere Untersuchungen wird die hochmolekulare DNA mit Restriktionsenzymen (DNasen) an bestimmten Stellen geschnitten und auf diese Weise in definierte, einfacher handhabbare Fragmente zerlegt. Eine Grundvoraussetzung der molekularbiologischen Analytik ist die Möglichkeit, solche DNA-Fragmente in Plasmide von Bakterien, meist Escherichia coli, einzubauen und in beliebig großer Menge identisch zu vermehren, Klonierung. Dadurch lassen sich genügende Mengen einer bestimmten DNA-Sequenz erzeugen, um mit biochemischen Methoden die Nucleotidabfolge zu ermitteln, Sequenzierung. Ein erster Schritt bei der Analyse von Pflanzengenen ist daher der Einbau von DNA-Stücken in geeignete bakterielle Plasmide, die als Vektoren in Bakterienzellen eingeschleust werden können. Hierbei reicht ein einziges Plasmid pro Zelle aus, um unter geeigneten Bedingungen auf einer Agarplatte eine Kolonie transformierter Zellen zu erzeugen, die als genetisch einheitliche Zelllinie, Klon, weitergeführt werden kann.

Der gewaltige Größenunterschied zwischen der Genomgröße des Zellkerns von Pflanzen mit etwa $10^{9}$ Nucleotiden und den in Plasmiden klonierten, direkt vollständig sequenzierbaren DNAFragmenten von etwa $10^{3}$ Nucleotiden macht es erforderlich, dass zunächst in Zwischenstufen größere Fragmente mit geeigneten Verfahren kloniert werden müssen. Hierbei nutzt man die Möglichkeit zur Konstruktion künstlicher Chromosomen in Hefezellen mit vermehrbaren DNAStücken von $10^{7}$ Nucleotiden (YAC = yeast artificial chromosome) und künstlicher Chromosomen in Bakterien (BAC = bacterial artificial chromosome).

Die Sequenzanalyse genomischer DNA-Fragmente ergibt eine Abfolge von Nucleotiden, die es meist direkt ermöglicht, ein Gen anhand seiner charakteristischen Merkmale zu erkennen. Proteincodierende Regionen lassen sich durch das Translationsstartcodon ATG und das anschlieBende, in eine Aminosäuresequenz übersetzbare Leseraster von jeweils 3 Nucleotiden pro Aminosäure erkennen. Auf diese Weise lässt sich die Aminosäuresequenz des Proteins vorhersagen. Dabei ist allerdings die Anwesenheit von Introns zu berücksichtigen, von denen in Pflanzengenen durchschnittlich 3-5 vorkommen. Man kann diese Unterbrechungen des proteincodierenden Leserasters in der genomischen Sequenz anhand der konservierten Intronkriterien erkennen, z. B. der Identität der Grenznucleotidsequenzen und dem gerade bei Pflanzen erhöhten A/T-Gehalt. Aus der vollständigen Sequenzinformation eines
Genoms sollte sich also theoretisch die Gesamtheit der darin codierten Aminosäuresequenzen vorhersagen lassen. Um diese grundlegende Information an einigen Pflanzenspezies beispielhaft zu ermitteln, haben sich weltweite $\mathrm{Zu}$ sammenarbeiten zwischen einer Vielzahl von Wissenschaftlern gebildet, die die vollständige Nucleotidsequenz der Kerngenome ausgewählter Modellpflanzen analysieren. Neben der Arabidopsis thaliana (Ackerschmalwand, Brassicaceae) mit einem der kleinsten bisher bekannten Pflanzengenome ( $\rightarrow$ S. 123) ist bereits die wichtige Nutzpflanze Reis (Oryza sativa) vollständig sequenziert.

Die vergleichsweise sehr kleinen Genome der Plastiden und Mitochondrien wurden bereits in vielen Spezies vollständig analysiert, z. B. in den Dikotylen Tabak und Arabidopsis, der Monokotyle Mais und dem Lebermoos Marchantia $(\rightarrow \mathrm{Ab}$ bildung 6.6). Solche genomischen Analysen ergeben zwar ein vollständiges Bild der codierten Aminosäuresequenzen, erlauben aber nur unvollständige Vorhersagen über die insgesamt enthaltenen Informationen, die teilweise nicht direkt aus der Aminosäuresequenz abgelesen werden können. Dazu gehört z. B. die Information über die Regulation der Genaktivität. Selbst wenn wir das offene Leseraster für ein Protein in der genomischen DNA identifizieren können, lassen sich daraus noch keine Rückschlüsse darauf ziehen, ob dieses Protein wirklich in der Pflanze gebildet wird, und, wenn ja, in welchen Zellen und in welchem Entwicklungszustand dieser Zellen diese Information genutzt wird.

Die in der Nucleotidsequenz der DNA niedergelegte genetische Information lässt sich auch ausgehend vom Endprodukt, dem Protein, aufklären. Man kann heute bereits bei sehr kleinen Mengen eines isolierten Proteins die Abfolge der Aminosäurereste in einem Teilstück bestimmen und daraus nach dem genetischen Code die möglichen Kombinationen von Nucleotidsequenzen vorhersagen, die für diesen Proteinabschnitt codieren. Damit kann die richtige Nucleotidsequenz in der genomischen DNA identifiziert werden. Alternativ können kurze Nucleotidabfolgen (Oligonucleotide) mit einer gewünschten Reihenfolge maschinell synthetisiert werden. Mit diesen künstlich hergestellten Gensonden lassen sich dann in Klonbanken diejenigen Bakterienlinien identifizieren, welche die entsprechende pflanzliche DNA-Sequenz enthalten.

Eine Klonbank (Klonbibliothek) ist die Gesamtheit der unterschiedlichen Bakterienkolonien, die jeweils ein bestimmtes DNA-Fragment aus dem Genom einer Pflanze enthalten. Dabei wird im ersten Klonierungsschritt die Gesamtheit der 
DNA-Fragmente unsortiert kloniert. Bei einer Gesamtzahl von einigen Millionen verschiedener solcher Klone ist mit großer Wahrscheinlichkeit jedes beliebige Stück der genomischen DNA in mindestens einem Klon vorhanden.

Klonbanken lassen sich aber nicht nur von genomischer DNA, sondern auch ausgehend von der mRNA-Population ganzer Pflanzen oder einzelner Gewebe anlegen. Da die Isolierung einzelner Proteine in zur Sequenzanalyse ausreichenden Menge oft sehr schwierig, oder, wie z. B. im Fall seltener Proteine, fast unmöglich ist, bietet die mRNA eine Möglichkeit, aktiv transkribierte Gene zu identifizieren. Dazu muss die aus der Pflanze isolierte mRNA in die komplementäre DNA (cDNA) umgeschrieben werden. Man nutzt hierbei die Fähigkeit der reversen Transkriptase, eines Enzyms aus RNA-Viren, auch in vitro eine getreue DNA-Kopie einer vorgegebenen RNAMatrize zu synthetisieren. Die cDNA kann wiederum in Bakterien kloniert werden und man erhält so eine cDNA-Bibliothek, in der in Form einzelner Klone alle mRNA-Typen der Pflanze vertreten sind. Die Sequenzanalyse der verschiedenen cDNA-Klone liefert dann ein umfassendes Bild aller in einer Pflanze oder einem Gewebe aktiven Gene. Der hierfür notwendige enorme Arbeitsaufwand wird derzeit wie die Genomanalysen von internationalen Konsortien verschiedener Laboratorien erbracht, die gemeinsam die Gesamtheit der exprimierten Sequenzbereiche (EST = expressed sequence tags) für Pflanzen wie Arabidopsis, Reis, Mais, Roggen und Sojabohne analysieren. folgt in dieser Richtung. Bei proteincodierenden Genen geben auf der linken Seite in der RNA das Startcodon AUG (ATG im nicht-transkribierten Strang der DNA) und auf der rechten Seite das Stopcodon, z. B. UAA in der RNA (TAA in der
DNA), die Grenzen der Translation an. Die Steuerzeichen für die Regulation der Transkription (Promotor) befinden sich meist vor der Initiationsstelle der Transkription. Wie bei der Transkription erfolgt dann auch die Translation in dieser Darstel-

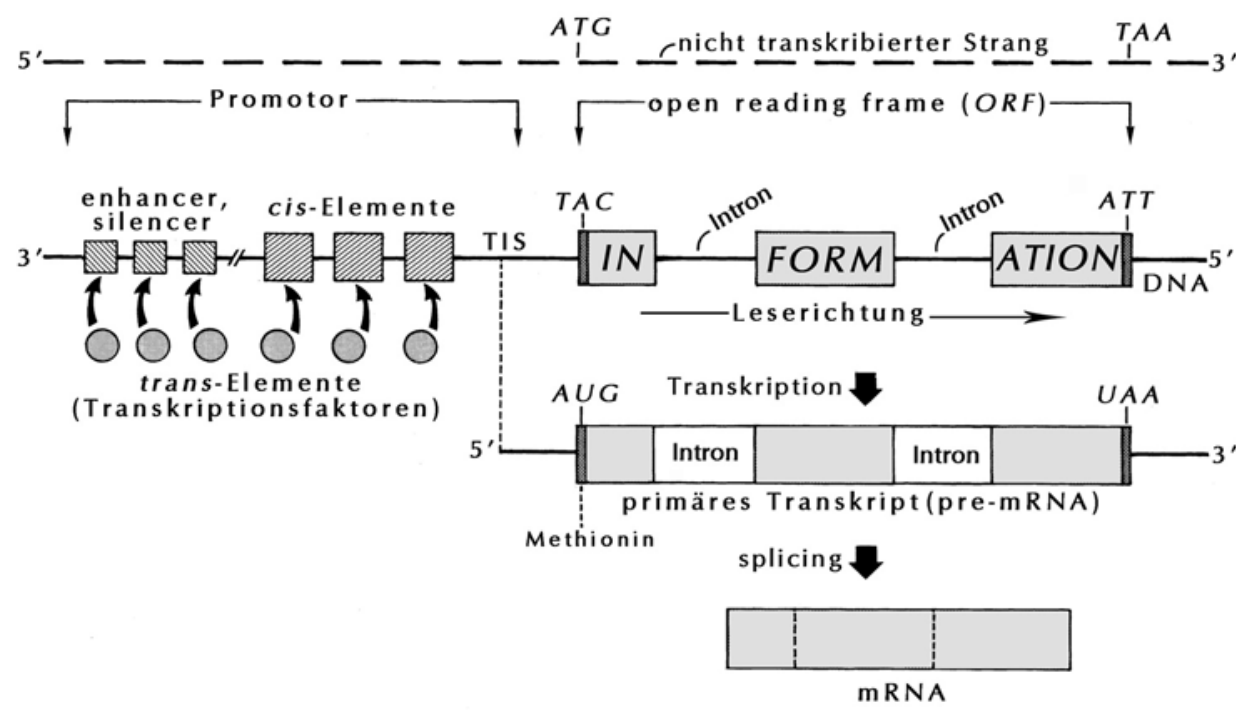

Abb. 6.1. Schematische Darstellung eines eukaryotischen proteincodierenden Gens. Die oft von Introns unterbrochene genetische Information der DNA (Summe der Exons) wird in RNA umgeschrieben. Das offene Leseraster (open reading frame, ORF) reicht vom Translationsstartcodon AUG bis zum Translationsstopcodon UAA (oder UAG, UGA). Der Beginn der Transkription (Transkriptionsinitiationsstelle, TIS) durch die RNA-Polymerase wird vom Promotor gesteuert, der fast beliebig viele cis-Elemente enthält. Diese werden von trans-Elementen (Transkriptionsfaktoren, DNA-bindenden regulatorischen Proteinen) erkannt und aktiviert oder inaktiviert. Aus dem primären Transkript (pre-mRNA) werden die Intronabschnitte herausgeschnitten (splicing). Die Summe der Exons liefert die mRNA und damit die Information für die Aminosäuresequenz bei der Translation. Zur Rekapitulation: In der DNA kommen die Basenpaare A-T (Adenin-Thymin) und G-C (Guanin-Cytosin) vor ( $\rightarrow$ Abbildung 1. 6). In der RNA tritt U (Uracil) an die Stelle von T. Der genetische Code bezeichnet die Basentripletts in der RNA, die für eine bestimmte Aminosäure codieren. Die entsprechenden Tripletts im abgelesenen Strang der DNA sind dazu komplementär. Bei der Beschreibung der DNA-Tripletts orientiert man sich konventionsgemäß am nicht-abgelesenen DNA-Strang. 
lung von links nach rechts, also vom Translationsinitationscodon AUG zum Translationsterminationscodon UAA (oder UAG, UGA).

\subsection{Die Organisation des Genoms}

\subsubsection{Die drei Genome der Pflanzenzelle}

Als Genom bezeichnen wir normalerweise die Gesamtheit der genetischen Information einer Zelle bzw. eines Organismus. Diese Definition wird aber schon bei Bakterien schwierig, die neben dem eigentlichen Bakterienchromosom zusätzlich noch Plasmide enthalten. Bei der tierischen Zelle finden wir genetische Informationen im Zellkern und in den Mitochondrien. In der Pflanzenzelle unterscheiden wir drei Genome, das nucleäre Genom im Zellkern, das plastidäre Genom in den Plastiden und das mitochondriale Genom in den Mitochondrien. Die DNAs dieser drei Genome können aufgrund ihrer meist unterschiedlichen Dichte voneinander getrennt werden (Abbildung 6.2).

Die evolutionsgeschichtliche Herkunft der drei Genome der Pflanzenzelle erklärt die Endosymbiontentheorie ( $\rightarrow$ Abbildung 2.24). Die gastgebenden Vorläufer der Eukaryoten nahmen zuerst die prokaryotischen Vorläufer der Mitochondrien auf: Bakterien, die gemeinsame Vorfahren und entsprechende Ähnlichkeiten mit den heutigen $\alpha$-Purpurbakterien (Proteobakterien) aufweisen. $\mathrm{Zu}$ dieser Gruppe gehören übrigens auch die heute mit Pflanzen eng vergesellschafteten Symbionten der Gattung Rhizobium und die Parasiten der Gattung Agrobacterium ( $\rightarrow$ S. 636). Die Plastiden entstanden deutlich später durch ein zweites endosymbiontisches Ereignis nach der Trennung der Evolutionswege zu den heterotrophen Eukaryoten, den Tieren, und den dann autotrophen Eukaryoten, den Pflanzen. Die Vorläufer der Plastiden sind in der Verwandtschaft der heutigen Bakterien mit oxygener Photosynthese vom Typ Prochloron und Cyanobakterien zu suchen. Die Genome in den Plastiden und Mitochondrien sind die Überreste dieser ehemals bakteriellen Genome. Das Genom des Zellkerns ist dagegen evolutionsgeschichtlich ein Mosaik aus Genen verschiedener Herkunft, aus Genen der gastgebenden Zelle und aus den im Laufe der Zeit aus den Plastiden und Mitochondrien zur besseren Informationsverwaltung transferierten prokaryotischen Genen. Der Zellkern und da-

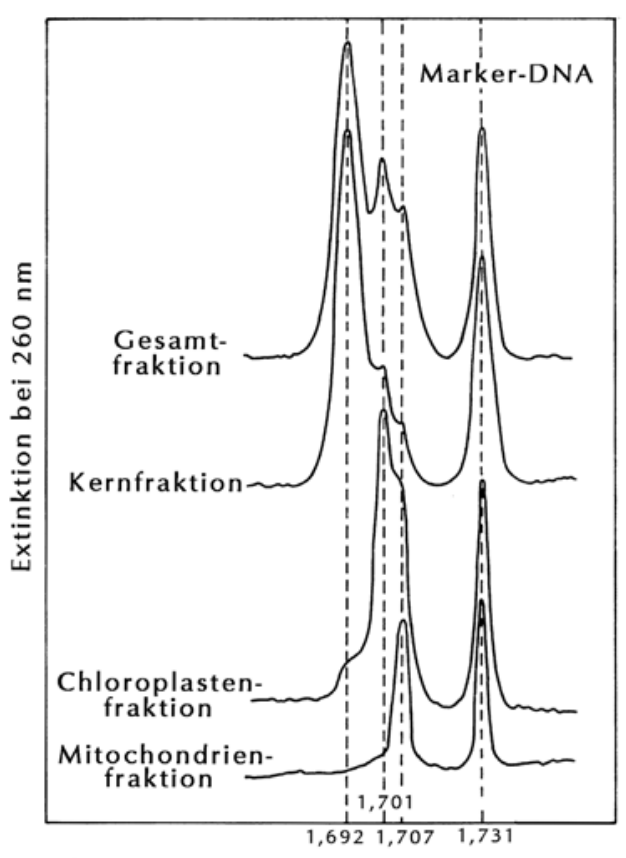

Auftriebsdichte im CsCl-Gradient $\left[\mathrm{g} \cdot \mathrm{cm}^{-3}\right]$

Abb. 6.2. Der biochemische Nachweis von nucleärer, plastidärer und mitochondrialer DNA. Objekt: Hypokotyl von Gurkenkeimlingen (Cucumis sativus). Die aus dem gesamten Gewebe bzw. aus Kern-, Chloroplasten und Mitochondrienfraktionen gewonnene DNA wurde, zusammen mit Marker-DNA aus Micrococcus lysodeikticus in einem isopyknischen $\mathrm{CsCl}$-Dichtegradienten bis zur Gleichgewichtseinstellung zentrifugiert. Anschließend wurde das DNA-Profil optisch ausgemessen. Man erkennt bei der Gesamtfraktion eine Aufspaltung in drei überlappende Extinktionsgipfel unterschiedlicher Dichte, welche sich durch die spezifische Anreicherung in den verschiedenen Zellfraktionen als Kern-, Plastiden- bzw. MitochondrienDNA identifizieren lassen. Der Dichtewert der nucleären DNA variiert bei verschiedenen Arten, so dass sich nicht immer eine so klare Aufspaltung ergibt. Auch ist bei den meisten anderen Pflanzen der Kern-DNA-Gehalt sehr viel größer als hier (nur 0,7 pg pro haploidem Genom; $\rightarrow$ Tabelle 6.1), so dass die Organellen-DNA leicht überdeckt werden kann. (Nach Kadouri et al. 1975)

mit die eukaryotische Zelle entstand bei der Fusion der Wirtszelle und den ersten Gastzellen, den späteren Mitochondrien.

Außerdem sind neue Gene hinzugekommen, die durch die endosymbiontische Situation notwendig wurden, z. B. Gene für den Transport von Proteinen in die Organellen. Schließlich ist im Verlauf der Evolution auch noch genetische Informationen von anderen Organismen, z. B. parasitierenden oder symbiontischen Pflanzen, Bakterien oder Pilzen aufgenommen worden. Eindrucksvolle Beispiele für diesen sogenannten horizontalen Gentransfer 
sind die mobilen Elemente wie Transposons und Retrotransposons, die, nur auf ihre eigene Vermehrung bedacht, Kerngenome von Pflanzen, Tieren oder Pilzen infizieren können $(\rightarrow$ Abbildung 6.5).

Entsprechend ihrer Herkunft sind die Genome der Pflanzenzelle unterschiedlich strukturiert, organisiert und reguliert. Die in diesen Genomen festgelegten genetischen Informationen werden unabhängig voneinander und auf unterschiedlichen Wegen zur nächsten Generation weiter gegeben. Während das Kerngenom nach den Mendelschen Regeln vererbt wird, werden die plastidären und mitochondrialen Genome nicht-mendelnd weitergegeben. Bei den Angiospermen dominiert die maternale Vererbung beider Genome über die Eizelle. In einigen Pflanzen, z. B. bei der Nachtkerze (Oenothera) kommt auch paternale Vererbung vor. In solchen biparentalen Erbgängen können Mitochondrien und Plastiden getrennt voneinander vererbt werden. Extreme Beispiele hierfür finden sich bei Coniferen, wo bei manchen Spezies Mitochondrien maternal und Plastiden paternal vererbt werden, während bei anderen Arten die Erbgänge umgekehrt verlaufen. In wieder anderen Arten werden beide Organellen rein paternal weitergegeben.

Obwohl die drei Genome getrennt sind, ist es im Laufe der Evolution immer wieder zu Gentransfers gekommen, so dass sich Fragmente aus einem der Genome auch in einem der anderen Genome finden. Diese Rekombination findet auch noch laufend statt, wobei sogar Gentransfers zwischen verschiedenen Pflanzenspezies vorkommen. Besonders durch den engen Kontakt bei Wirt-ParasitKontakten scheinen solche DNA-Transfers begünstigt zu werden.

\subsubsection{Genomstruktur im Zellkern}

Wie in tierischen Zellen ist die DNA im Kern von Pflanzenzellen in mehrere lineare Moleküle aufgeteilt, die jeweils als Hyperstruktur ein Chromosom bilden. Die einzelnen DNA-Moleküle sind mit einer Ausdehnung von bis zu mehreren Metern viel zu lang, als dass sie in lockerer Form im Zellkern untergebracht werden könnten. Durch Assoziation mit bestimmten Proteinen (Histonen und NichtHistonen) wird die DNA in mehreren Stufen stark aufgeschraubt und gefaltet (Abbildung 6.3). Die maximale Verkürzung wird in der Form des Meta- phasechromosoms während der Mitose erreicht. Die transkriptionsaktiven Interphasechromosomen liegen in einer vergleichsweise stark aufgelockerten Form vor, insbesondere diejenigen Bereiche, in denen Gene abgelesen werden. Die Verpackung der Chromosomen ist so konstruiert, dass der Zugriff zu den aktiven Genbereichen nicht wie z. B. bei einem Tonband linear abläuft, sondern, eher vergleichbar einer $\mathrm{CD}$, abschnittsweise erfolgen kann. Die unterste Stufe der Verpackung, die für die Transkription geöffnet werden muss, ist das Nucleosom, in dem ein Abschnitt von etwa 200 Nucleotidpaaren der DNA mit 8 Histonmolekülen komplexiert ist ( $\rightarrow$ Abbildung 6.3). Die Grenzen der Nucleosomen auf dem DNA-Strang sind für DNasen relativ leicht zugänglich und lassen sich so identifizieren. Inaktive DNA-Regionen, z. B. in stillgelegten Bereichen des zweiten, homologen Chromosoms im diploiden Organismus, sind auch durch eine starke Methylierung der Basen gekennzeichnet.

Sehr viel häufiger als bei Tieren beobachtet man bei Pflanzen das Phänomen der Polyploidie. Diese tritt auch bei Nachkommen aus Kreuzungen nahe verwandter Arten hervor, die als Nutzpflanzen gezüchtet wurden. So enthalten z. B. der hexaploide Weizen und die tetraploide Kartoffel drei bzw. zwei diploide Genome der Vorfahren. Solche polyploiden Pflanzen sind meist kräftiger im Wuchs und höher im Ertrag. Diese Form der Polyploidie ist keine identische Vermehrung des Erbguts, da die Chromosomensätze aus verschiedenen Elterngenomen stammen, und hauptsächlich deshalb behalten werden, weil sie eben nicht mehr identisch zueinander sind. Solche Nichtidentitäten von Chromosomensätzen führen im Extremfall dazu, dass, wie z. B. in der Gattung Oenothera, selbst in einem diploiden Organismus die beiden Chromosomensätze so unterschiedlich sind, dass es bei der Meiose zu keiner Paarung, und damit auch zu keinem crossover zwischen den homologen Chromosomen kommt. Von dieser durch Kreuzung entstandenen Polyploidie zu unterscheiden ist die Endopolyploidie, d.h. die identische Vermehrung des diploiden Chromosomensatzes, die in bestimmten spezialisierten Zellen während der Entwicklung der vielzelligen Pflanze regelmäßig auftritt, z. B. in Drüsenzellen oder in den Geleitzellen der Siebröhren $(\rightarrow S$. 337), also in solchen Zellen, die eine besonders hohe Stoffwechselaktivität und Proteinsynthesekapazität aufweisen. 


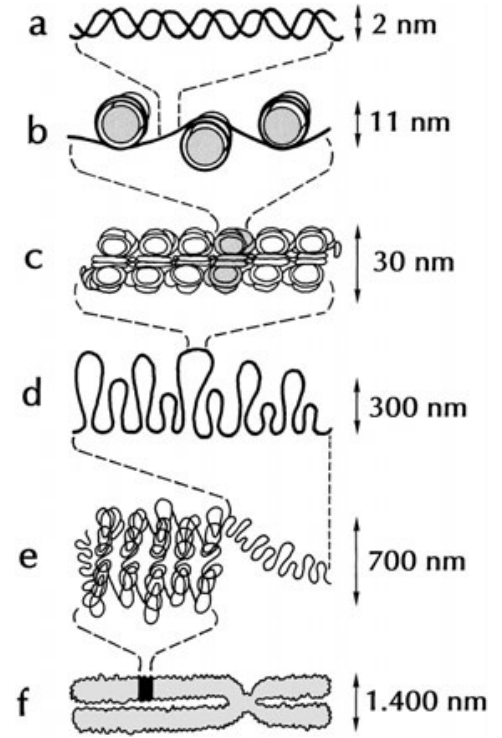

Abb. 6.3 a-f. Die Stufen der Chromatinkondensation in einem Chromosom. a gestrecktes DNA-Molekül. In dieser Form ist ein Chromosom mehrere Meter lang. b Verkürzung durch lokale Aufrollung um Histone zur Nucleosomenstruktur. c Verdichtete Nucleosomenstruktur. d Weitere Verkürzung durch Schleifenbildung. e Ausbildung einer Wendelstruktur, wie sie im maximal kondensierten Metaphasechromosom (f) vorliegt. In dieser Transportform (etwa $10 \mu \mathrm{m}$ ) ist die DNA nicht transkribierbar. Im Interphasekern liegt das Chromosom dagegen in einer zumindest partiell stark aufgelockerten Form vor, welche die Transkription einzelner Gene erlaubt. (Nach Lea und Leegood 1993; verändert)

Die Mengen an DNA im Zellkern schwanken nicht nur wegen der unterschiedlichen Ploidiegrade sehr stark zwischen einzelnen Pflanzenarten, sondern auch, und insbesondere, wegen des sehr unterschiedlichen Anteils an wiederholten (repetitiven) DNA-Sequenzen im Genom. Mehrfach vorkommende (amplifizierte) genetische Information betrifft zum einen nicht-codierende DNA, zum anderen codierende Regionen, z. B. die ribosomalen RNA-Gene (rDNA), die im Nucleolus in mehreren tausend Kopien vorliegen können. Dabei sind die meisten Kopien dieser Gene untereinander identisch; kleinere Unterschiede in der DNA-Sequenz finden sich in den wenig konservierten (variablen) Genbereichen und in der spacer-Region zwischen den Genen. Die große Zahl dieser Gene reflektiert den hohen Bedarf der Zelle an den entsprechenden Genprodukten, den ribosomalen RNAs, die in der Regel über $90 \%$ der gesamten RNA der Zelle ausmachen $(\rightarrow$ Exkurse 6.2 und 6.3).
Durch Amplifikation von proteincodierenden Genen sind im Verlauf der Evolution im Kerngenom viele Genfamilien entstanden, deren Mitglieder je nach Entstehungszeitpunkt und Selektionsdruck mehr oder weniger verschieden wurden. Evolutionärer Selektionsdruck auf die einzelnen Gene einer Genfamilie entsteht z. B. durch unterschiedliche Anforderungen an ihre Funktion in verschieden differenzierten Zellen. So gehören etwa Gene für verschiedene Formen des Photoreceptors Phytochrom zu einer Genfamilie, die in verschiedenen Entwicklungsstadien der Pflanze für spezifische Steuerfunktionen eingesetzt werden $(\rightarrow \mathrm{Ab}$ bildung 19.17). Auch sehr häufige Proteine, z. B. das mengenmäßig häufigste Protein der Welt, das Enzym Ribulosebisphosphatcarboxylase/oxygenase (RUBISCO; $\rightarrow$ S. 466), werden oft durch Genfamilien codiert.

Die auffällig verschiedenen DNA-Gehalte verschiedener Pflanzen beruhen aber nur zu einem geringen Teil auf Unterschieden in der Menge an genetischer Information, wie sie z. B. beim Vergleich von Phagen, Bakterien und Eukaryonten offensichtlich sind (Tabelle 6.1). Bei Pflanzen finden wir selbst bei nahe verwandten Spezies oft stark schwankende DNA-Mengen pro haploidem Genom (Tabelle 6.2). Die DNA der Plastiden und Mitochondrien steuert meist weniger als $5 \%$ zum DNA-Gehalt pflanzlicher Zellen bei. Die Unterscheidung in nicht-repetitive Kern-DNA, die die

Tabelle 6.1. Menge an DNA pro haploidem Genom. 1 pg (Picogramm) DNA entspricht 965 MB (Megabasenpaare $=10^{6}$ Basenpaare). (Nach Rees 1976)

\begin{tabular}{ll} 
Organismus & DNA-Menge [pg] \\
\hline T4-Phagen & 0,00022 \\
\hline Escherichia coli & 0,0045 \\
\hline Saccharomyces cerevisiae & 0,026 \\
\hline Drosophila melanogaster & 0,10 \\
\hline Maus & 2,50 \\
\hline Mensch & 3,20 \\
\hline Lathyrus angulatus & 4,50 \\
\hline Lathyrus sylvestris & 11,6 \\
\hline Salamander salamander & 32,0 \\
\hline Picea abies & 50,0 \\
\hline a Nach Nagel (1976) &
\end{tabular}




\section{EXKURS 6.2: Wie isoliert man ein aktives Gen?}

Während die Sequenzanalyse der genomischen DNA die insgesamt vorhandene genetische Information liefert, so erhält man aus der cDNA-Sequenzanalyse die in der Pflanze abgelesene Information. In den verschiedenen Geweben einer Pflanze wird jeweils ein teilweise unterschiedlicher Anteil der genetischen Information benötigt. Dies ist z. B. offensichtlich bei der spezifischen Synthese von Speicherproteinen in Samen, nicht aber in anderen Geweben der Pflanze. Die Abbildung zeigt die stadienspezifische Expression einiger mRNAs für Speicherproteine während der Entwicklung des Soja-Samens (Glycine max). Die massive gewebe- und entwicklungsspezifische Expression von Genen für Speicherproteine wird besonders deutlich während der Samenreifung. In Gesamt-RNA-Präparationen sind die ribosomalen RNAs die dominanten RNA-Moleküle, die bei der Größenfraktionierung durch Gelelektrophorese sichtbar werden, so z. B. in dem Bacterium Escherichia coli (E. coli) oder im Embryo der Sojabohne. In der Analyse der Poly(A)enthaltenden mRNA-Moleküle wird in verschiedenen Stadien der Embryogenese die unterschiedliche Genaktivierung zwischen der frühen Stufe der Embryoentwicklung, dem Keimblattstadium, dem mittleren Reifungsstadium und dem späten Reifungsstadium deutlich. Die mRNAs für einige der Speicherproteine bzw. ihrer Untereinheiten lassen sich hier deutlich unterscheiden. (Nach Goldberg et al. 1989)

An diesem Beispiel wird bereits auf der Ebene der mRNAs die stadienspezifische Aktivierung bestimmter Informationen deutlich. Sind die gewebe- oder zellspezifisch gebildeten mRNAs in solch hohen Mengen vorhanden wie im Fall von Samengeweben, so lassen sie sich direkt isolieren und nach Umschreibung in cDNAs in ihrer Sequenz analysieren. In vielen anderen Fällen sind jedoch die spezifisch aktivierten mRNAs, insbesondere die regulatorisch wirksamen mRNAs, nur in sehr geringer Menge vorhanden und müssen durch Eliminierung der Masse der unspezifisch aktiven mRNAs mit Hilfe von cDNA-Subtraktionsverfahren angereichert werden. Dies gelingt z. B.

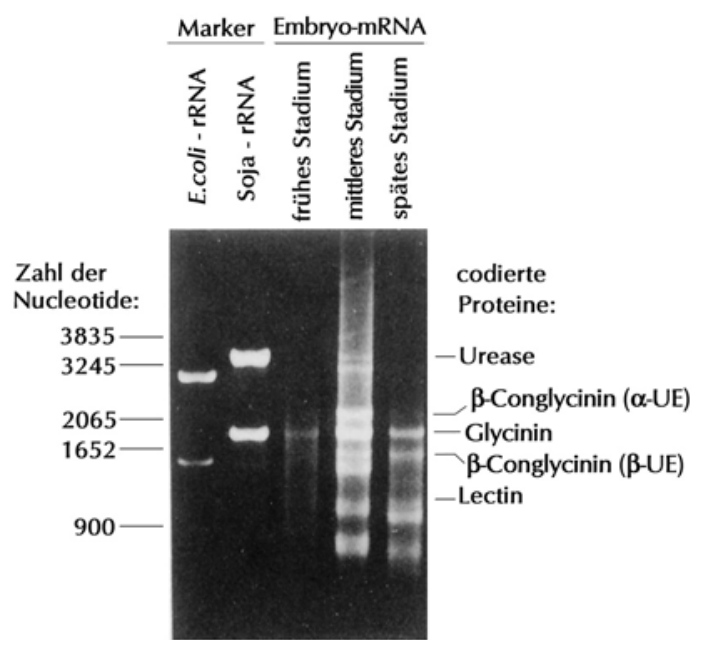

auf folgendem Weg: Um die durch Licht induzierten mRNAs einer Pflanze zu isolieren, stellt man cDNA-Populationen aus der gesamten mRNA lichtgewachsener bzw. dunkelgewachsener Pflanzen her. Wenn man nun die cDNA aus Dunkelpflanzen im Überschuss an ein unlösliches Trägermaterial bindet und die cDNA aus Lichtpflanzen damit inkubiert, werden alle sequenzgleichen Moleküle der cDNA aus Lichtpflanzen durch komplementäre Basenpaarung, Hybridisierung, an das Trägermaterial gebunden und können abgetrennt werden. Die restliche, nicht gepaarte CDNA enthält alle diejenigen Sequenzen, die nur in der mRNA der Lichtpflanzen vorliegen. Diese lassen sich dann in E. coli klonieren und anschließend sequenzieren. Für die Gene sehr seltener Proteine, z. B. Transkriptionsfaktoren oder anderer regulatorischer Proteine, die nur in wenigen Zellen der Pflanze und in kurzen Lebensphasen, z. B. bei der Blühinduktion im Meristem exprimiert werden, sind diese biochemischen Verfahren meist nicht ausreichend empfindlich. In diesem Fall müssen genetische Methoden herangezogen werden, um die Gene im Genom zu lokalisieren und anschließend zu isolieren. eigentlich wichtige, übersetzbare Information trägt, und in repetitive Kern-DNA zeigt, dass die Unterschiede hauptsächlich auf den variablen Anteil an repetitiver DNA zurückzuführen ist. Der für die Transkription nutzbare Anteil des pflanzlichen Kerngenoms ist auf einen engen Abschnitt im G + C-Profil der Gesamt-DNA beschränkt, deren G + C-Gehalt im Rahmen einer Verteilungskurve vari- iert (Abbildung 6.4). Die repetitive DNA besteht hauptsächlich aus stark amplifizierten DNA-Sequenzen meist unbekannter Funktion (SatellitenDNA) und transposablen Elementen. Bei Arabidopsis thaliana mit einem der kleinsten bisher bekannten Kerngenome ( $0,15 \mathrm{pg} /$ haploides Genom) findet man nur wenige Kopien solcher Sequenzen, während z. B. bei Lilien lange Transposons bzw. Retro- 


\section{EXKURS 6.3: Wie isoliert man ein Gen über Mutagenese?}

Schwach transkribierte Gene, z. B. regulatorische Gene, kann man über Mutationen und die mit diesen Genstörungen einhergehenden Phänotypen isolieren. Hierzu werden große Pflanzenpopulationen mutagenisiert und die interessanten Phänotypen isoliert, um das betroffene Gen zu identifizieren und zu klonieren. Die Mutationen werden durch Behandlung von Samen oder Pollen mit chemischen Mutagenzien oder ionisierender Strahlung erzeugt und lassen sich dann mit klassischen genetischen Verfahren in Heterozygoten- und Homozygotenlinien in ihrer phänotypischen Ausprägung analysieren. Um das gestörte Gen zu isolieren, muss zunächst seine Lage auf einem Chromosom ermittelt, und innerhalb des Chromosoms immer feiner eingeengt werden, Genkartierung. Durch eine meist aufwendige Analyse von Koppelungsgruppen mit anderen Merkmalen lässt sich die Position einer Mutation bis auf einige 1000 Nucleotide genau eingrenzen. Dabei wird insbesondere die Koppelung mit oft zufällig ausgewählten Restriktionslängenpolymorphismen (RFLP = restriction fragment length polymorphism) und anderen kurzen Nucleotidabfolgen in cross-over-Experimenten genutzt. Die so definierte Region der einzelnen Mutation kann dann aus genomischen Klonbanken isoliert und analysiert werden.

Andere Ansätze zur Isolierung mutierter Gene über ihren Phänotyp versuchen nicht einzelne Nucleotide zu verändern, die nur mit viel Mühe auffindbar sind, sondern ein Gen durch den Einbau eines DNA-Fragments zu stören. In dieser Form ist das mutierte Gen markiert und kann sehr elegant als links oder rechts angrenzende Sequenz direkt isoliert werden (gene tagging). Für diesen Zweck wird z. B. die Fähigkeit mobiler DNA-Elemente, Transposons, genutzt, von einem Ort im Genom an einen anderen zu springen und sich dort in die DNA einzufügen. Mit diesem
Transposon-tagging wurden z.B. Gene für die Biosynthese von Anthocyanen und deren Regulation in Mais und Löwenmäulchen erfolgreich isoliert. Ein Nachteil dieser Methode ist, dass Transposons bevorzugt in räumlich naheliegende Chromosomenbereiche springen, so dass die Insertionsorte nicht statistisch über das Genom verteilt sind.

Ein alternativer Ansatz nutzt die Eigenschaft des Ti-Plasmids aus Agrobacterium tumefaciens, bei der Infektion einer Pflanzenzelle die T-DNA irgendwo in das nucleäre Genom zu integrieren $(\rightarrow$ S. 637). Für die Modellpflanze Arabidopsis existieren weltweit nutzbare Populationen von Mutanten, bei denen die T-DNA an jeweils verschiedenen Stellen ins Genom integriert ist, und die nun anhand ihrer phänotypischen Defekte selektioniert werden können. Mit solchen Insertionsmutanten lassen sich sehr elegant diejenigen Gene identifizieren, die an der Ausprägung bestimmter Merkmale beteiligt sind. Außerdem kann man unter Umständen anhand solcher Mutantenpopulationen auch bereits die Funktion eines noch unbekannten Gens ableiten. Wird bei der genomischen Analyse ein offenes Leseraster als Kandidat für ein neues Gen identifiziert, so kann die Gesamtheit der Insertionsmutatnen darauf untersucht werden, ob eine Linie enthalten ist, in der dieses Gen verändert wurde. Findet man eine solche Linie, so erlaubt ihr Phänotyp Rückschlüsse auf die Funktion dieses Gens. Dabei taucht allerdings das Problem auf, dass sowohl bei der Transposonmutagenese als auch bei der T-DNA-Insertionsmutagenese in den betroffenen Zellen oft mehrere Einbauereignisse stattfinden, die anschließend einzeln weiter analysiert werden müssen, um einen klaren kausalen $\mathrm{Zu}$ sammenhang zwischen Gen und Funktion herzustellen. transposons (2-8 Kilobasenpaare, abgekürzt: kB) in mehr als 100.000 Kopien vorliegen (Abbildung 6.5).

Bei der durch Mitosen erfolgenden Vervielfachung des Kerngenoms während der Entwicklung einer Pflanze bleibt dieses inhaltlich unverändert. Dadurch erhalten sich die Zellen die genetische Omnipotenz, die Grundlage dafür, dass aus einzelnen Zellen potenziell wieder ein vollständiger Organismus regenerierbar ist. Als Ausnahme hat man bei Flachs (Linum usitatissimum) reversible Änderungen der Genomstruktur und des Gengehalts pro
Zelle beobachtet, die durch unterschiedliche Düngung hervorgerufen werden können. In aller Regel kann man jedoch davon ausgehen, dass das Genom einer Pflanze während der Ontogenese konstant bleibt.

\subsubsection{Das plastidäre Genom}

Das Genom der Plastiden besteht aus ringförmigen oder linearen DNA-Molekülen ohne Histone oder andere, der Verpackung dienenden Proteine. Die Zellen der höheren Pflanzen enthalten 5-50 Plasti- 
Tabelle 6.2. Menge an repetitiver und nichtrepetitiver DNA in pg pro haploidem Genom bei Lathyrus-Arten mit unterschiedlichen DNA-Mengen. (Nach Narayan und Rees 1976)

\begin{tabular}{llll} 
Art & $\begin{array}{l}\text { Gesamt- } \\
\text { DNA }\end{array}$ & $\begin{array}{l}\text { nicht- } \\
\text { repetitive } \\
\text { DNA }\end{array}$ & $\begin{array}{l}\text { repetitive } \\
\text { DNA }\end{array}$ \\
L. articulatus & 12,45 & 5,48 & 6,98 \\
\hline L. nissolia & 13,20 & 5,41 & 7,78 \\
\hline L. clymenum & 13,75 & 5,23 & 8,52 \\
\hline L. ochrus & 13,95 & 5,58 & 8,37 \\
\hline L. aphaca & 13,97 & 5,17 & 8,80 \\
\hline L. cicera & 14,18 & 5,96 & 8,22 \\
\hline L. sativus & 17,15 & 5,23 & 11,90 \\
\hline L. tingitanus & 17,88 & 6,93 & 10,95 \\
\hline L. hirsutus & 20,27 & 6,17 & 14,10 \\
\hline
\end{tabular}

den mit je 10-200 Genomkopien, d.h. sie sind bezüglich des Plastidengenoms hochgradig polyploid. Bei den meisten Pflanzen sind zusätzlich die rRNAGene und einige angrenzende DNA-Sequenzen dupliziert und liegen als inverted repeats vor (IR; Abbildung 6.6). Die Größenunterschiede zwischen den

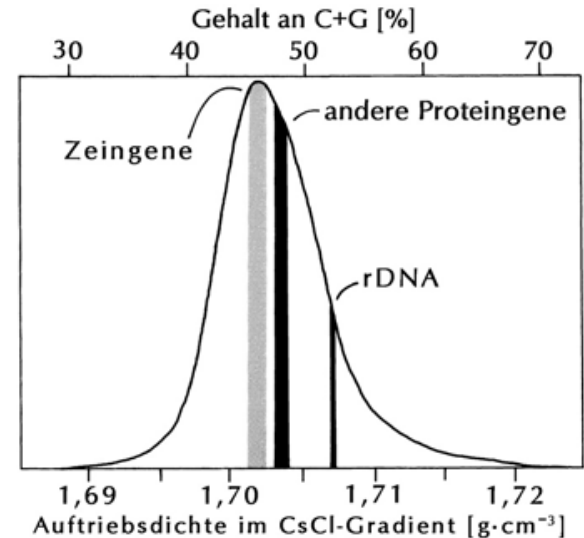

Abb. 6.4. Verteilung des $\mathrm{G}+\mathrm{C}$-Gehalts in der DNA von Mais (Zea mays). Bei diesem Experiment wurden DNAFragmente von 50-150 kB in einem analytischen $\mathrm{CsCl}$ Dichtegradienten aufgetrennt. Die für Proteine codierenden Abschnitte des Kerngenoms liegen überwiegend in einem engen Dichtebereich mit einem bestimmten $\mathrm{G}+\mathrm{C}$ Gehalt. Die Zeingene, die für die Speicherproteine im Maiskorn codieren, haben einen etwas geringeren $\mathrm{G}+\mathrm{C}$ Gehalt als die Mehrheit der proteincodierenden Gene. Bei der hier bestimmten Dichteverteilung ist zu berücksichtigen, dass in Mais wie in den meisten anderen Pflanzen ein Großteil der DNA stark methyliert vorliegt und daher zu niederen Dichtewerten verschoben ist. Im rDNA-Bereich liegen die Gene für die ribosomalen RNAs. Der Bereich der Gene für allgemeine Proteine repräsentiert den Durchschnitt aus 265 Maisgenen aus der Datenbank. Für die Zeingene wurden 41 Gene zugrunde gelegt. (Nach Carels et al. 1995)
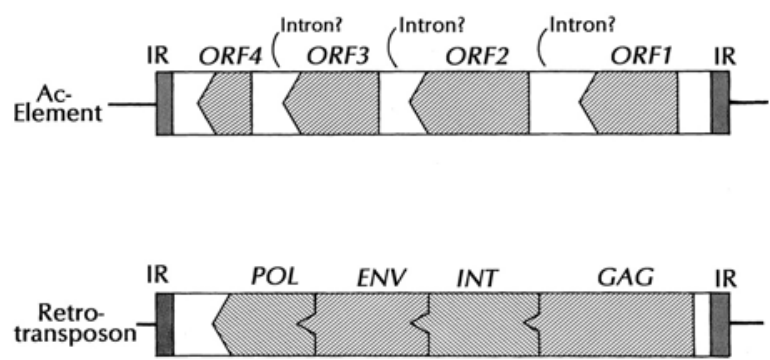

Abb. 6.5. Transposon- und Retrotransposonelemente im Kerngenom von Pflanzen. Neben vielen, oft nur wenige $100 \mathrm{~B}$ langen Sequenzwiederholungen tragen auch größere, häufig vorkommende DNA-Elemente zu den enormen Größenunterschieden zwischen den Kerngenomen verschiedener Pflanzenspezies bei. Das transposable Element Ac wird in der Praxis für die genetische Analyse insbesondere bei Mais, aber auch bei anderen Pflanzenspezies eingesetzt. Dieses Element springt im Genom von einer Position an eine andere, sobald es durch bestimmte zelluläre Bedingungen mobilisiert wird. Dabei kommt es zur Inaktivierung des betroffenen Gens. Zu der Grundstruktur solcher Transposons gehören Sequenzwiederholungen an den Enden (inverted repeat, IR) und verschiedene Leseraster (ORF), die möglicherweise unter Eliminierung von Intronsequenzen auf RNA-Ebene zusammengefügt werden. Funktionen der dort codierten Proteine beinhalten u. a. das korrekte Herausschneiden, die Mobilität und das Wiedereinsetzen dieses DNA-Segmentes. Ähnliche Funktionen sind auch auf den Retrotransposonelementen codiert, die in allen Pflanzen im Kerngenom gefunden werden. Retrotransposons sind vermutlich aus im Genom etablierten Retroviren entstanden und enthalten an ihren Enden ebenfalls wiederholte Sequenzabschnitte $(I R)$. Die dort codierten Funktionen beinhalten eine RNA-abhängige DNAPolymerase - die reverse Transkriptase (POL), ein Mobilitätsprotein (GAG), eine Integrasefunktion (INT) und ein Hüllprotein (ENV). Fragmente solcher mobiler Retrotransposons finden sich in Kopienzahlen bis zu mehreren Millionen im Zellkern verschiedener Pflanzenspezies. Teile solcher Retrotransposonelemente wurden auch im mitochondrialen Genom von Pflanzen identifiziert. 
Plastidengenomen verschiedener Pflanzen $(121 \mathrm{kB}$ bei Marchantia, $156 \mathrm{kB}$ bei Tabak) beruhen zum größten Teil auf dem unterschiedlichen Umfang dieser Duplikation. Variationen im Gengehalt finden sich zwischen den relativ weit voneinander entfernten Entwicklungslinien der Algen und höheren
Pflanzen. Bei einer ganzen Reihe von Pflanzen, z. B. bei Marchantia, Arabidopsis und einigen Algenarten sind die Plastidengenome vollständig sequenziert und die Genprodukte identifiziert worden, so dass wir einen guten Überblick über ihren Informationsgehalt besitzen (Abbildung 6.6). Ein wesentlicher

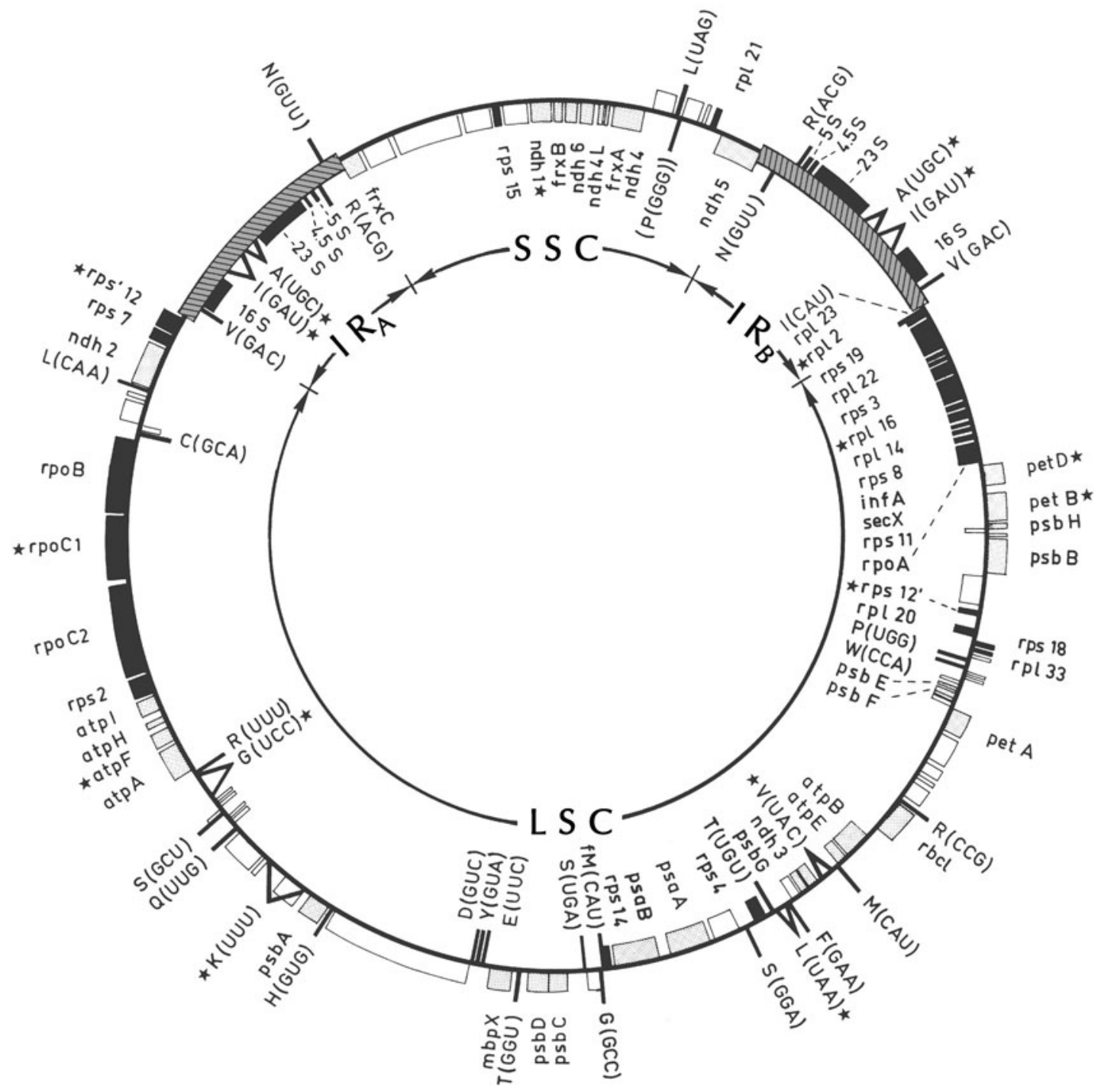

Abb. 6.6. Genkarte des Plastidengenoms im Lebermoos Marchantia polymorpha. Das circuläre DNA-Molekül umfasst $121 \mathrm{kB}$. Der innere Kreis gibt die beiden inverted repeats $\left(I R_{A}, I R_{B}\right)$ und die large single copy (LSC)- und small single copy (SSC) Regionen wieder. Die Gene, die auf der Innenseite der Genkarte eingetragen sind, werden im Uhrzeigersinn, jene auf der Außenseite im Gegenuhrzeigersinn transkribiert. Gene für rRNAs sind durch 4,5S, 5S, 16S, 23S gekennzeichnet. Gene für tRNAs sind durch den jeweiligen Aminosäurecode (nichtmodifiziertes Anticodon) markiert. Identifizierte Proteingene sind durch Gensymbole gekennzeichnet (punktierte Kästchen: Gene des Photosyntheseapparates, schwarze Kästchen: Gene des Transkriptions- und Translationsapparats). Einige Beispiele: rbcl, große Untereinheit der Ribulosebisphosphatcarboxylase/oxygenase; $p s a, p s b$, Untereinheiten von Photosystem I bzw. II, atp, Untereinheiten der ATP-Synthase; pet, Untereinheiten des Cytochrom-b/f-Komplexes; rps, rpl, ribosomale Proteine; rpo, RNA-Polymerase. Die offenen Kästchen bezeichnen die bisher noch nicht aufgeklärten offenen Leseraster. Gene, die Introns enthalten, sind mit Sternchen markiert. (Nach Umesono und Ozeki 1987; verändert) 
Teil des Plastidengenoms (etwa die Hälfte) codiert für Funktionen der Informationsverwaltung und -umsetzung in den Plastiden, z. B. für alle 4 rRNAs, alle 30 tRNAs, einem Drittel der ribosomalen Proteine und Teile einer RNA-Polymerase. Die andere Hälfte steht für die Codierung von etwa 20 Enzymproteinen zur Verfügung, vor allem für Untereinheiten von Proteinkomplexen des Photosyntheseapparats in den Thylakoiden, der RUBISCO und der plastidären ATP-Synthase.

Anders als im nucleären Genom, aber in Übereinstimmung mit dem Genom der Prokaryoten, sind die Gene im Plastidengenom oft zu funktionellen Einheiten, Operons, zusammengefasst, welche von einem gemeinsamen Promotor reguliert werden (Abbildung 6.7). Die hohe Gendichte unterliegt einem Selektionsdruck unbekannter $\mathrm{Na}$ tur, der dafür sorgt, dass nicht unbedingt benötigte Information sehr schnell wieder aus dem Genom entfernt wird. Besonders drastische Beispiele hierfür sind sekundär parasitische Pflanzen, die keine Photosynthese mehr durchführen, sondern sich durch Anzapfen der Saftströme in den Wurzeln anderer Pflanzen heterotroph ernähren $(\rightarrow$ S. 641). In den stark verkleinerten Plastidengenomen dieser Parasiten finden sich nur noch Gene, die für die Energieumsetzung im Dunkeln und die Aufrechterhaltung von Transkription und Translation notwendig sind, während die Gene für Photosynthesefunktionen weitgehend verschwunden sind.

Bei manchen Algen sind die heutigen Plastidengenome erst durch sekundäre Endosymbioseereignisse entstanden, z. B. bei den Cryptomonaden und Chlorarachniophyten $(\rightarrow$ Abbildung
2.24). In diesen Evolutionslinien sind ganze eukaryotische, photosynthetisch aktive Algenzellen in andere Eukaryoten aufgenommen worden und haben anschließend einen Teil ihrer mitgebrachten genetischen Information verloren, bis hin zur völligen Aufgabe des eigenen Zellkerns. Die Zell- und Plastidenmembranen blieben jedoch teilweise erhalten, so dass jetzt die Plastiden von drei oder vier Hüllmembranen umgeben sind.

\subsubsection{Das mitochondriale Genom}

Der prokaryotische Ursprung des ebenfalls ringförmigen oder linearen mitochondrialen Genoms wird wie beim Plastidengenom an einer Reihe von Merkmalen deutlich, wobei aber auch charakteristische Unterschiede zwischen den beiden Organellen auftreten. Wie im Plastiden ist die Kopienzahl der mitochondrialen Genome pro Zelle variabel und vom Entwicklungsstadium abhängig (20-2.000 DNA-Moleküle pro Zelle). Vollständige Sequenzinformationen liegen derzeit von den $\mathrm{Mi}$ tochondriengenomen des Lebermooses Marchantia und mehreren höheren Pflanzen, unter anderem Arabidopsis, vor. Die Mitochondriengenome verschiedener Pflanzenspezies unterscheiden sich in einzelnen Genen, z. B. für ribosomale Proteine. Ihre sehr unterschiedliche Größe $(185 \mathrm{kB}$ bei Marchantia, $369 \mathrm{kB}$ bei Arabidopsis) ist nicht auf einen unterschiedlichen Informationsgehalt, sondern auf eine Vergrößerung der nichtcodierenden DNA-Bereiche bei Arabidopsis zurückzuführen (Tabelle 6.3). In dieser Hinsicht sind die Mitochondriengenome den Kerngenomen ähnlich; in beiden Fällen

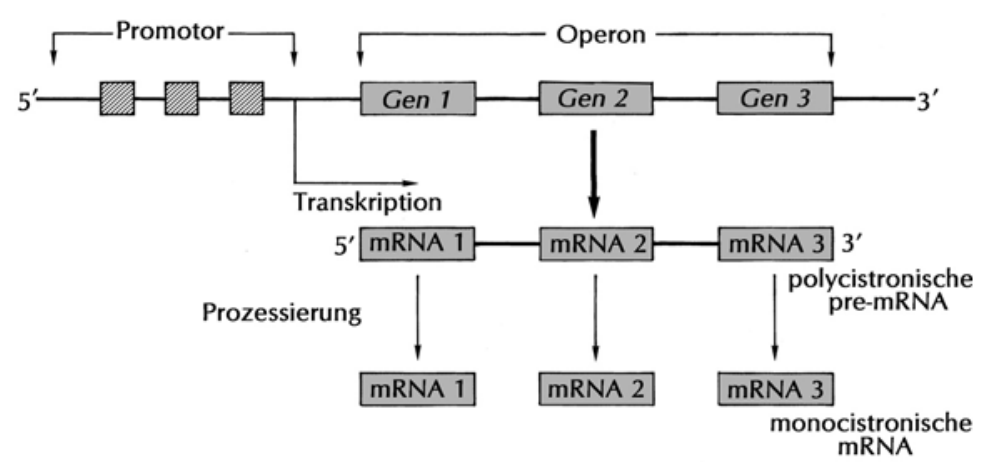

Abb. 6.7. Operonstruktur bei plastidären Genen. Im plastidären Genom liegen wie im prokaryotischen Genom oft mehrere Gene benachbart auf dem DNA-Strang und werden in eine polycistronische mRNA übersetzt, die anschließend in einzelne mRNAs zerlegt wird. Die Transkription dieser Gene wird über einen gemeinsamen Promotor reguliert. Derartig organisierte Operonstrukturen kommen in den heutigen Prokaryoten und in den aus eingewanderten Prokaryoten stammenden Genomen der Plastiden und Mitochondrien vor. Im Kerngenom ist die Operonstruktur auf die Gene für die ribosomalen RNAs beschränkt. 
scheint ein nur geringer Selektionsdruck auf Größe und Informationsdichte zu herrschen. Unter den nicht-codierenden Sequenzen im mitochondrialen Genom finden sich auch Fragmente aus dem Plastidengenom und aus dem Kerngenom sowie Reste von Transposons und parasitischen RNA-Viren, die sonst nur bei phytopathogenen Pilzen gefunden werden ( $\rightarrow$ Exkurs 6.4). Der Umfang der Mitochondriengenome verschiedener Pflanzen reicht von etwa $200 \mathrm{kB}$ bei einigen Brassica-Arten bis $\mathrm{zu}$ 2.500 kB beim Kürbis.

EXKURS 6.4: Wie erhält man Hinweise auf die Funktion eines Gens über Strukturähnlichkeiten mit anderen Genen?

Die genomische Identifizierung eines potenziell neuen Gens durch DNA-Sequenzierung oder Mutagenese erfordert weitere Analysen, um Hinweise auf die molekulare Funktion der darin codierten RNA bzw. des Proteins zu erhalten. Da weltweit alle neu identifizierten Gensequenzen und -funktionen in zentralen Datenbanken wie der Genbank in den USA und dem European Molecular Biology Laboratory (EMBL) eingespeichert werden, liegt dort eine laufend aktualisierte Sammlung aller bekannten Gensequenzen und häufig auch ihrer Funktion vor. Mit einer neu aufgefundenen, unbekannten Gensequenz lassen sich nun diese Datensammlungen auf ähnliche Sequenzen durchsuchen. Durch Vergleich mit der Vielzahl der inzwischen bekannten Gene ist es oft möglich, auf diesem Weg Hinweise auf die Funktion eines neu gefundenen Gens zu bekommen. Es ist z. B. möglich, dass ein strukturell ähnliches, evolutionär verwandtes Gen in einer anderen Organismusgruppe, sei es Tier, Bacterium, Archaeon oder einer anderen Pflanzenordnung, bereits aufgeklärt wurde. Dann kann das neue Gen direkt als evolutionäres Homolog gleicher oder ähnlicher Funktion charakterisiert werden.

Finden sich über Sequenzvergleiche keine solchen direkt homologen Gene, so lassen sich oft auch über partielle Ähnlichkeiten in der Aminosäuresequenz des Proteins wahrscheinliche Funktionen ableiten. Proteinregionen, die die Bindung bestimmter Cofaktoren wie z. B. Metallionen vermitteln oder an der Interaktion mit anderen Proteinen beteiligt sind, enthalten meist charakteristische Strukturen, die auch zwischen Proteinen verschiedener Funktion ähnlich sind. Dabei stellt sich heraus, dass nicht nur ganze Proteine bzw. Gene in ihrer Einheit in der Evolution erhalten geblieben sind, sondern auch einzelne Abschnitte als funktionelle Module neu gemischt wurden und so zur Entstehung neuer Gene führten.

Auch innerhalb eines Genoms findet man oft mehrere verwandte Gene, insbesondere für solche Proteine, die ähnliche Funktionen in verschiedenen Bereichen des Stoffwechsels oder in verschiedenen Entwicklungsstadien der Pflanzen erfüllen müssen. So findet man z.B. eine Familie von Genen für Phytochrome, die aus einem Gen durch Duplikation entstanden sind und sich im Verlauf der Evolution sowohl im codierenden Bereich als auch im Promotor so verändert haben, dass jetzt mehrere, leicht unterschiedliche Proteine auftreten, deren Gene spezifisch reguliert werden können ( $\rightarrow$ Abbildung 19.17).

Verwandte Gene lassen sich aber auch direkt experimentell identifizieren. Bei der SouthernAnalyse (benannt nach Ed Southern, der diese Methode entwickelte) wird die energetisch recht stabile Basenpaarung zwischen einzelnen DNAMolekülen komplementärer Sequenz ausgenützt, DNA/DNA-Hybridisierung. Zunächst wird die aus einem Gewebe isolierte DNA mit Restriktionsenzymen in unterschiedlich große Stücke zerlegt. Diese Fragmente werden dann durch Elektrophorese in einer Gelmatrix entsprechend ihrer Größe aufgetrennt, wobei die kleinsten Moleküle die größte Wanderungsgeschwindigkeit aufweisen. Die bisher noch doppelsträngige DNA wird dann durch eine Alkalibehandlung denaturiert, d.h. in Einzelstränge gespalten, vom Gel auf eine Membranfolie überführt und dort immobilisiert. Nun werden einzelsträngige $A b$ schnitte des zu untersuchenden Gens in radioaktiv markierter Form als Sonde auf die Folie gebracht. Bei der Hybridisierungsreaktion suchen sich die Abschnitte die komplementären Sequenzen auf der Folie und werden dort festgehalten. Im Autoradiogramm lässt sich dann die Größe dieser Sequenzen anhand der Wanderungsstrecke im Gel bestimmen. Aus der Zahl der radioaktiv markierten Banden ergibt sich die Zahl gleicher oder ähnlicher Gene in dem analysierten Genom. Durch Absenkung der Hybridisierungstemperatur oder Veränderung der Salzkonzentration lassen sich die Hybridisierungsbedingungen so lockern, dass nicht nur gleiche, sondern auch ähnliche DNA-Sequenzen von der Sonde erkannt werden. Mit dieser Methode kann man also auch verwandte Gene identifizieren, z. B. lassen sich in der Mais-DNA homologe Gene mit Sonden aus Arabidopsis-DNA aufspüren. Auch der Umfang einer Genfamilie lässt sich mit einer solchen Southern-Analyse ermitteln. 
Tabelle 6.3. Zusammensetzung des mitochondrialen Genoms von Arabidopsis thaliana

\begin{tabular}{lc} 
& $\begin{array}{c}\text { prozentualer } \\
\text { Anteil }\end{array}$ \\
\hline identifizierte Gene & 16 \\
\hline nicht-identifizierte, offene Leseraster & 10 \\
\hline $\begin{array}{l}\text { rekombinante und andere } \\
\text { Sequenzwiederholungen }\end{array}$ & 7 \\
\hline Sequenzen plastidären Ursprungs & 1 \\
\hline Sequenzen nucleären Ursprungs & 4 \\
\hline Sequenzen ungeklärter Funktion & 62 \\
\hline
\end{tabular}

Auch im Mitochondrion nimmt die Information für den eigenen genetischen Apparat einen großen Teil der codierenden Kapazität ein. Daneben codieren mitochondriale Genome für einige hydrophobe Untereinheiten der Atmungskettenkomplexe und der mitochondrialen ATP-Synthase $(\rightarrow$ Abbildung 4.8). Obwohl genug Kapazität zur Verfügung stünde, sind nicht einmal alle mitochondrialen tRNAs im Mitochondrion selbst codiert und müssen daher teilweise aus dem Cytoplasma importiert werden.

Während wir in den verschiedenen Pflanzengruppen einschließlich der Algen ähnliche Anzahlen mitochondrialer Gene für rRNAs finden, treten bei den Genen für die ribosomalen Proteine deutliche Unterschiede auf. Bei der Analyse solcher Unterschiede zeigte sich, dass manche dieser Gene in späteren Phasen der Evolution aus dem mitochondrialen Genom in das Kerngenom transferiert wurden und daher jetzt bei einigen Pflanzen im Organell, bei anderen im Kern codiert sind (Abbildung 6.8).

\subsection{Die Transkriptionspromotoren, RNA-Polymerasen und RNA-Reifung}

\subsubsection{Transkription nucleärer Gene}

Die Umsetzung der genetischen Informationen von der DNA in die Aminosäuresequenz der Proteine erfordert als ersten Schritt die Transkription der Basenfolge in der DNA in die der mRNA ( $\rightarrow$ Exkurse 6.5 und 6.6). Die Startzeichen für diese Um-
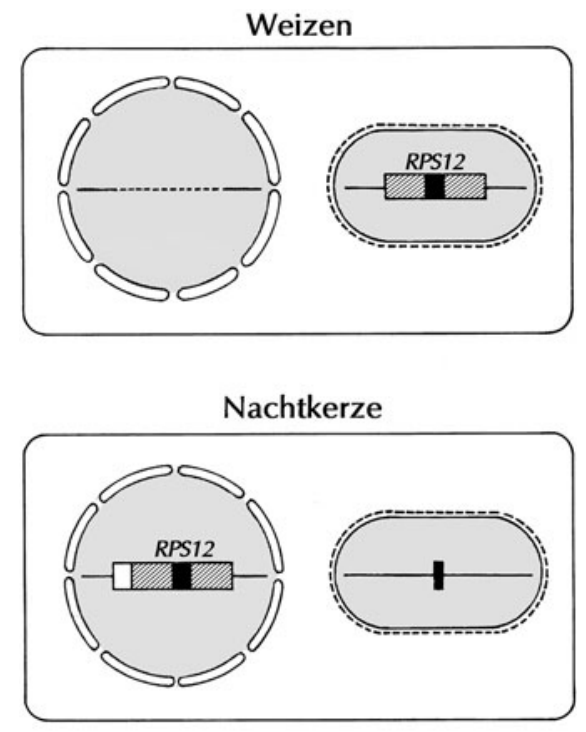

Abb. 6.8. Translokation eines Gens aus dem mitochondrialen Genom in den Zellkern. Das Gen für das Protein 12 der kleinen ribosomalen Untereinheit (RPS12) in den Mitochondrien ist beim Weizen (Triticum) im mitochondrialen Genom codiert. In der Nachtkerze (Oenothera) ist dagegen im mitochondrialen Genom nur noch ein kleines Fragment dieses Leserasters vorhanden; der andere Teil ging durch Rekombinationsereignisse verloren. Im Zellkern von Weizen findet sich, soweit bekannt, kein Gen für das Protein RPS12, während bei der Nachtkerze das vollständige Gen im Kern vorliegt. Dabei wurde am 5'-Ende eine zusätzliche Sequenz angehängt, so dass das Protein mit dieser Signalsequenz korrekt in die Mitochondrien importiert werden kann. Dieses Beispiel aus der relativ jungen Evolutionsgeschichte bestätigt die Endosymbiontentheorie, die genau solche Gentransferprozesse während der funktionellen Etablierung der Plastiden und Mitochondrien in der eukaryotischen Zelle postuliert.

schreibung werden durch den Promotor gegeben, der, unter Mithilfe verschiedener DNA-bindender Proteine, Transkriptionsfaktoren, als Ansatzpunkt für die RNA-Polymerase dient und unmittelbar vor dem Startpunkt der Transkription liegt $(\rightarrow$ Abbildung 6.1).

Für die wichtigsten Genklassen finden wir im Zellkern drei verschiedene RNA- Polymerasen, die bei allen eukaryotischen Organismen den gleichen evolutionären Ursprung haben. Die RNA-Polymerase I schreibt spezifisch die ribosomalen RNA-Gene ab, während die RNA-Polymerase II für alle proteincodierenden Gene, und die RNA-Polymerase III für alle tRNA-Gene und andere kleine, meist nucleolär lokalisierte RNA-Sequenzen zuständig sind. Insbesondere die Transkription der proteincodierenden Gene bedarf einer spezifi- 
schen, vom Entwicklungsprogramm der Zelle abhängigen Regulation. Die Promotoren dieser Gene sind besonders variabel und kompliziert aufgebaut. Sie enthalten zusätzlich zu charakteristischen Sequenzen (TATA-Box, CAAT-Box; Abbildung 6.9), meist eine Vielzahl regulatorisch wirksamer cis-Elemente, die mit einer entsprechenden Anzahl von Transkriptionsfaktoren interagieren (Abbildung 6.10). Selbst bei den Genen für einzelne Untereinheiten eines Proteinkomplexes, die ähnlichen regulatorischen Anforderungen unterliegen, sind die Promotoren oft unterschiedlich aufgebaut. Es ist daher in vielen Fällen nicht möglich, einen einfachen, klaren Zusammenhang zwischen Promotorstruktur und der auf der mRNA- oder Proteinebene beobachteten Spezifität der Genexpression herzustellen.

Die frisch transkribierten RNA-Moleküle, Primärtranskripte, pre-mRNAs, müssen erst noch diverse Reifungsschritte, Prozessierung, durchlaufen, bevor sie funktionsfähig werden. Ein solcher Schritt ist das Herausschneiden der Introns aus den pre-mRNAs, splicing. In proteincodierenden Genen findet man im Schnitt 4-5 solcher Intronsequenzen mit einer Länge von 50-5.000 Basen. Sie sind durch einen relativ hohen AT-Gehalt und durch bestimmte Motive an den Enden gekennzeichnet, die ihre Faltung zu einer Lassostruktur und das Herausschneiden durch Spliceosomen ermöglichen. Die nach Entfernung der Introns zusammengefügten mRNA-Exons werden am 5 '-Ende mit einer Cap-Struktur (7-Methylguanosyldiphosphat $=\mathrm{m}^{7} \mathrm{GPP}$ ) versehen, die dieses Ende vor dem Angriff durch Exonucleasen schützt. Das 3'Ende des Transkripts wird durch Anfügen einer etwa 200-gliedrigen Poly(A)-Kette stabilisiert $(\rightarrow$ Abbildung 6.14). Die so gereiften und stabilisierten

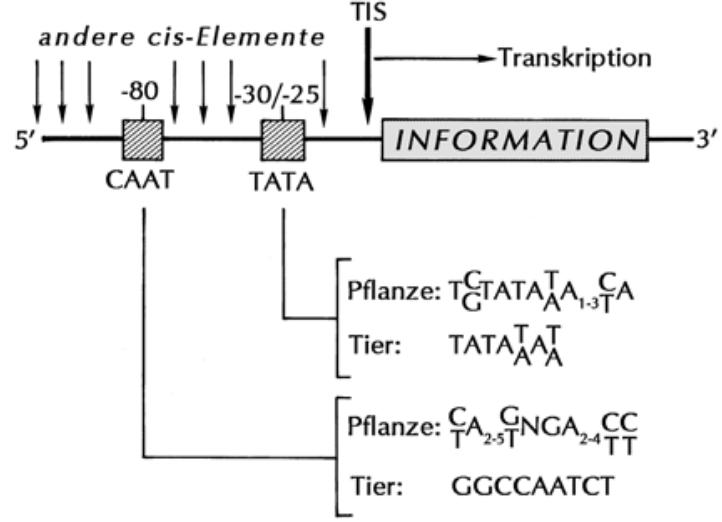

Abb. 6.9. Charakteristische Elemente in den Promotoren proteincodierender Gene im Zellkern. Bei Pflanzen sind, wie bei Tieren, im wesentlichen zwei Erkennungselemente (cis-Elemente) für Steuerfaktoren der Transkription (trans-Elemente) regelmäßig erkennbar. Das eine Element, die sog. TATA-Box, liegt 25-30 Nucleotide stromaufwärts vom ersten transkribierten Nucleotid (Transkriptionsinitiationsstelle, $T I S$ ). Das zweite Element, die sogenannte CAAT-Box, liegt weitere 50 Nucleotide stromaufwärts und ist bei Pflanzen wesentlich weniger gut konserviert als bei Tieren. Die Variationsmöglichkeiten in der Basensequenz sind durch alternative Buchstaben angegeben ( $\mathrm{N}=$ beliebiges Nucleotid).

mRNAs werden vom Kern ins Cytoplasma entlassen, wo die Umsetzung ihrer Information bei der Proteinsynthese am Ribosom stattfindet.

\subsubsection{Transkription plastidärer Gene}

In den Plastiden wird die genetische Information der DNA von zwei verschiedenen RNA-Polymerasen in RNA überschrieben. Eine davon ist eine typische prokaryotische RNA-Polymerase, die im Plastidengenom selbst codiert ist. Entsprechend

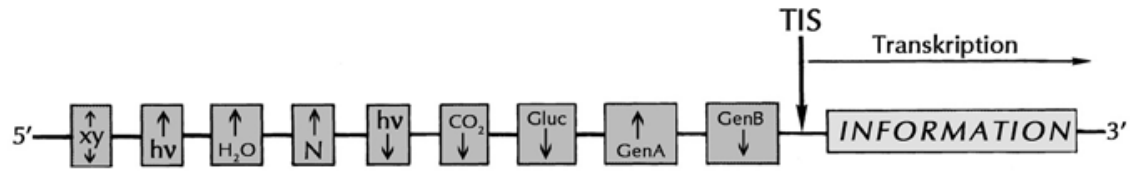

Abb. 6.10. Einige Beispiele für cis-Elemente im Promotor eines proteincodierenden Gens, die die Transkriptionsaktivität beeinflussen können. Die in der allgemeinen Genstruktur ( $\rightarrow$ Abbildung 6.1) als cis-Elemente bezeichneten Promotorabschnitte können über die Bindung spezifischer trans-Elemente durch ganz unterschiedliche Faktoren (Signale) beeinflusst werden. So kann z. B. die Transkription der genetischen Information durch die Aktivität anderer Gene (Gen A bzw. Gen $B$ ) verstärkt $(\uparrow)$ oder abgeschwächt $(\downarrow)$ werden. Metabolische oder physikalische Parameter wie die Konzentration an Glucose (Gluc), $\mathrm{CO}_{2}$, Stickstoff $(\mathrm{N})$, die verfügbare Feuchtigkeit $\left(\mathrm{H}_{2} \mathrm{O}\right)$, das Licht $(h v)$ oder noch unbekannte Faktoren $(x, y)$ können die Expression eines Gens über derartige Wechselwirkung im Promotor verändern. Ein und derselbe Promotor kann, z. B. durch Licht, an verschiedenen cis-Elementen auch gegensätzlich beeinflusst werden. Die Gesamtheit der cis-trans-Wechselwirkungen im Promotor bestimmt die Intensität, mit der die RNA-Polymerase die Transkription durchführt. 


\section{EXKURS 6.5.: Wie analysiert man die Expression eines Gens in der Pflanze?}

Die gewebespezifische Regulation der Genexpression kann am einfachsten über die Menge an gebildeten RNAs analysiert werden. Dazu isoliert man zunächst aus dem Gewebe die gesamte RNA. Aufgrund der Polyadenylierung am 3'-Ende lässt sich die cytoplasmatische mRNA-Fraktion von den nicht polyadenylierten tRNAs und rRNAs abtrennen, die den überwiegenden Anteil der Gesamt-RNA ausmachen. Man nützt hierzu die Basenpaarung zwischen dem Poly(A)-Schwanz der mRNAs und Oligodesoxythymidin (Oligo-dT)Ketten aus, die an ein unlösliches oder magnetisches Trägermaterial gebunden sind und daher nach ihrer Beladung mit der Poly(A)-RNA leicht abgetrennt werden können. Die so gereinigten Poly(A)-RNA-Moleküle können nun durch Elektrophorese entsprechend ihrer Größe aufgetrennt, auf eine Membran übertragen und dort immobilisiert werden. Der nächste Schritt dieser, in Anlehnung an die Southern-Analyse auch als northern-Analyse bezeichneten Methode, ist die Hybridisierung der aufgetrennten mRNAs mit einer im Überschuss zugefügten, radioaktiv markierten DNA-Sonde, in der Regel ein Fragment des zu untersuchenden Gens, DNA/RNA-Hybridisierung. Die Sonde bindet an die zu ihr komplementäre mRNA und macht diese im Autoradiogramm als Schwärzung sichtbar. Dabei entspricht die Stärke der Schwärzung in etwa der Menge an vorhandener mRNA. Diese Art der Hybridisierung erlaubt auch die Identifizierung und mikroskopische Lokalisierung bestimmter mRNAs in Gewebeschnitten, in-situ-Hybridisierung. Damit lässt sich die Expression bestimmter Gene in einzelnen Geweben nachweisen. Als Beispiel ist in der Abbildung die Lokalisierung der mRNA für die Speicherproteine Vicilin (B) und Legumin (C) in einem Querschnitt durch die Kotyledonen von reifenden Vicia faba L.-Embryonen (A) gezeigt. Die Lokalisierung der spezifischen mRNA ist jeweils als helle Zone zu sehen. Die radioaktive ${ }^{33}$ P-Markierung wurde mit einer Photoemulsion durch Dunkelfeldmikroskopie aufgenommen. Während die mRNAs für die beiden Speicherproteine hauptsächlich in den inneren Zellen der Kotyledonen exprimiert werden, ist die mRNA für den Saccharosetransporter VfSUT1 (D) in der morphologisch unteren Epidermis zu finden. (Aufnahmen von L. Borisjuk, 2005)

Die Aktivität eines Gens kann auch auf der Proteinebene untersucht werden, wenn passende Nachweismethoden dafür vorhanden sind. Als spezifische Proteinsonden verwendet man häufig Antikörper, die gegen das zu untersuchende Protein gerichtet sind. Die gesamte, aus einem Gewebe isolierte Proteinfraktion wird elektrophoretisch aufgetrennt, auf eine Membran über-
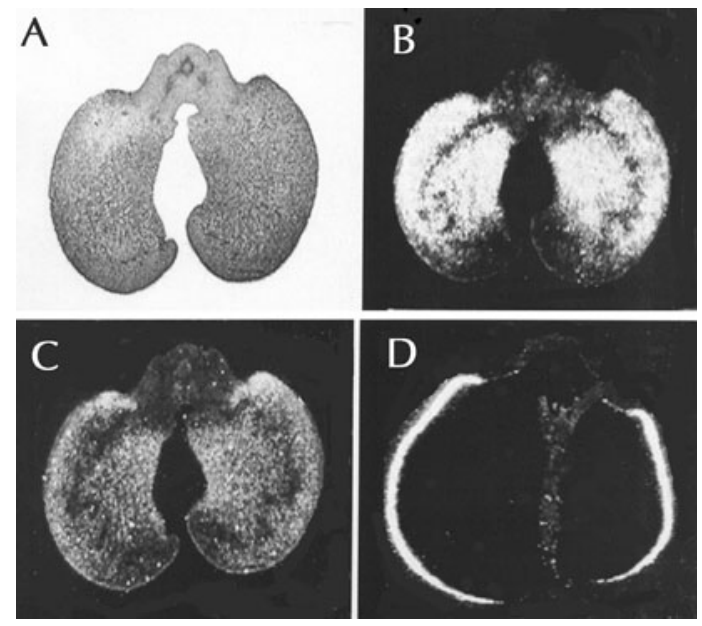

tragen und dort immobilisiert. Nach Reaktion mit einem Überschuss des spezifischen Antikörpers wird dieser auf der Membran sichtbar gemacht, z. B. durch Bindung eines zweiten, gegen den ersten gerichteten Antikörper, der mit einem Farbreagenz markiert ist oder mit einem Enzym gekoppelt ist, das eine Farbreaktion katalysiert. Aufgrund der hierbei erzielten Verstärkerwirkung sind solche Nachweismethoden in der Lage, Proteine im Picogramm-Bereich sichtbar zu machen. Voraussetzung für dieses, auch als western-Analyse bezeichnete Verfahren ist die Verfügbarkeit des reinen Proteins zur Erzeugung von Antikörpern in Kaninchen oder Mäusen. Zur Gewinnung des Proteins können auch das Gen oder die entsprechende cDNA als Ausgangsmaterial dienen. Die in einem Plasmid in E. coli klonierte genomische DNA oder cDNA kann mit bakteriellen Expressionsignalen versehen die Bakterien dazu veranlassen, das zugehörige Protein zu synthetisieren. Außerdem stehen heute auch zellfreie Transkriptions-Translations-Systeme zur Verfügung, z.B. auf der Basis von Weizenkeimextrakten, die alle Bestandteile der zellulären RNA- und Proteinsynthesemaschinerie enthalten und die Synthese eines Proteins anhand seiner DNA-Sequenz in vitro durchführen. Das gereinigte Protein wird dann in Tieren zur Antikörperproduktion eingesetzt. Analog zur DNA/RNA-Hybridisierung kann man Antikörper auch zur in-situ-Lokalisierung von Proteinen in Gewebeschnitten einsetzen und damit die Expressionsmuster eines Gens auf der Ebene der Translationsprodukte studieren. Die Verwendung von Antikörpersonden, an die elektronendichte Goldpartikel gebunden sind, erlaubt die Lokalisierung von Proteinen auch auf der elektronenmikroskopischen Ebene. 
EXKURS 6.6: Wie analysiert man Expression und Funktion eines Gens mit transgenen

Pflanzen?

Die experimentelle Möglichkeit, Pflanzen gezielt genetisch zu verändern, eröffnet verschiedene Wege, die Expression und Funktion von Genen zu analysieren. Transgene Pflanzen erhält man, indem man Fremdgene in pflanzliche Genome einbaut und dort zur Expression bringt. Die verschiedenen, heute zur Verfügung stehenden Verfahren zur Einschleusung von DNA in Pflanzenzellen und ihrer stabilen oder transienten Integration in das Kerngenom werden an anderer Stelle ausführlich behandelt ( $\rightarrow$ S. 659); hier wollen wir nur kurz auf einige Anwendungsmöglichkeiten in der Forschung eingehen, die die stabile Transformation von Pflanzenzellen eröffnet.

Mit der Reportergenanalyse lässt sich die Funktionsweise und Gewebespezifität von Promotoren bzw. einzelnen Promotorelementen, sowie von RNA-Stabilitätsfaktoren untersuchen. Hierbei wird die zu untersuchende Promotorsequenz vor ein Reportergen gesetzt und dieses Fusionsgen in das Genom einer Pflanze eingebaut. Unter einem Reportergen versteht man ein Gen, das in der Pflanze nicht vorkommt und dessen Produkt, das Protein, mit einer einfachen, spezifischen Testreaktion qualitativ, und gegebenenfalls auch quantitativ, nachgewiesen werden kann. Häufig wird zu diesem Zweck das Gen für eine bakterielle $\beta$-Glucuronidase (GUS) verwendet, das ein geeignetes Glucuronid unter Bildung eines unlöslichen blauen Farbstoffs spaltet und damit diejenigen Zellen durch Blaufärbung markiert, in denen der Promotor aktiv ist (siehe farbige Abbildung auf der Buchvorderseite). Abbildung A zeigt den in-situ-Nachweis des GUS-Reportergens, um gewebespezifische Genexpression sichtbar zu machen. Dazu wurde das GUS-Gen an Promotoren von Genen aus der AtBCAT-Genfamilie gekoppelt, die für Enzyme des Stoffwechsels verzweigtkettiger Aminosäuren codieren (Arabidopsis thaliana branched-chain aminotransferases) und das Konstrukt in das Genom von Arabidopsis eingebaut. Die im Bild dunkel erscheinende Blaufärbung in einem Rosettenblatt einer transformierten Pflanze (unten) weist auf entsprechende Promotoraktivitäten in den basalen Leitbündeln hin (oben: nicht transformierte Kontrolle). (Daten und Aufnahmen von Schuster und Binder, 2004)

Ein anderes oft benutztes Reportergen ist das GFP-Gen aus einer Quallenart. Das GFP-Protein (green fluorescent protein) kann durch Belichtung zur Emission von grünem Licht angeregt und auf diese Weise auch in vivo in der Pflanze sichtbar gemacht werden, ohne dass Stoffwechselstörungen durch eine chemische Reaktion zu
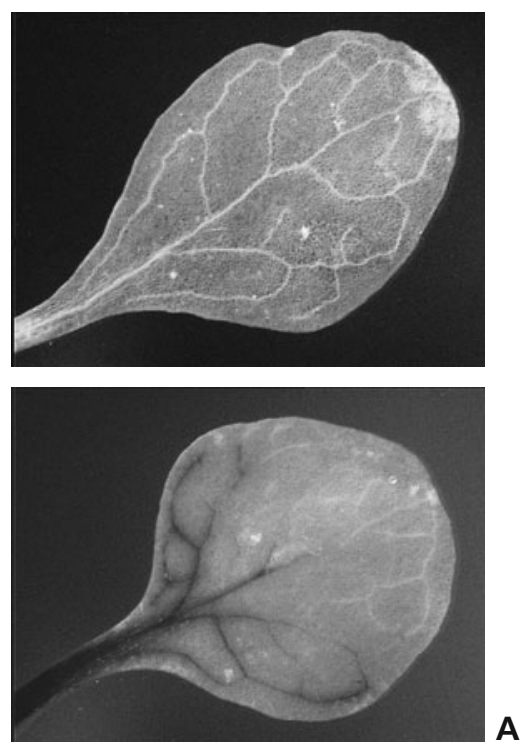

befürchten sind. Die geringe Diffusion dieses Proteins erlaubt es sogar, einzelne Zellareale oder Organellen mit dem Protein spezifisch zu markieren.

Beispielsweise ist es möglich, das GFP-Protein durch die Verknüpfung mit geeigneten Signalsequenzen in die Chloroplasten oder Mitochondrien importieren zu lassen und anhand der Fluoreszenz die Verteilung dieser Organellen in der Zelle zu studieren. Abbildung B zeigt eine solche transgene Expression des GFP zur spezifischen Markierung von bestimmten Organellen. In dieser transgenen Zelle einer Tabaksuspensionskultur wurde das Gen für das GFP-Protein mit einem mitochondrialen Signal versehen, das das fluoreszierende Protein spezifisch in diese Organellen importiert. In der Gesamtansicht der Zelle wird anhand der durch Belichtung induzierten Fluoreszenz die Verteilung der einzelnen Mitochondrien deutlich. Strich: $10 \mu \mathrm{m}$.

Mit der antisense-Technik ist es möglich, die Aktivität von bestimmten Genen zu hemmen. Dazu wird das aus der Pflanze isolierte Gen, meist in der Form einer CDNA-Sequenz, in umgekehrter Orientierung hinter den ursprünglichen oder einen anderen Promoter gesetzt und in das Genom eingebaut. Dies hat zur Folge, dass die Pflanze eine mRNA produziert, die komplementär zur (sense-)mRNA des eigenen Gens ist. Antisenseund sense-mRNA-Moleküle können nun durch Basenpaarung Hybride bilden und werden in dieser Form sehr viel schneller als die sense-mRNA abgebaut ( $\rightarrow$ Abbildung 28.14). Diese Technik erlaubt es also, die Bildung bestimmter Proteine in 


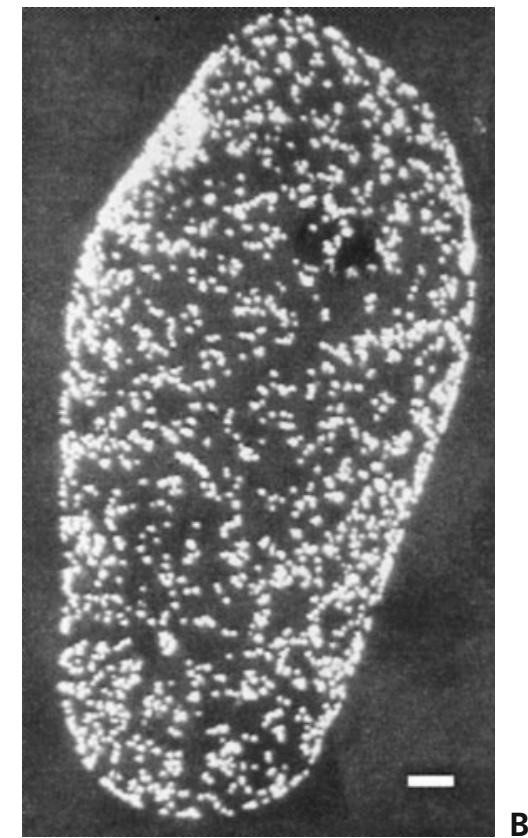

der Pflanze dauerhaft zu unterdrücken. Damit können z.B. einzelne enzymatische Reaktionen gezielt lahmgelegt und so Aufschlüsse über die Funktion der Enzyme für Entwicklung und Stoffwechsel erhalten werden.

Oft bessere (d. h. reproduzierbarere und stärkere) Abschaltungen von Genen lassen sich durch die Nutzung der endogenen RNA-InterferenzMaschine (RNAi) erreichen ( $\rightarrow$ S. 398). Eigentlich zur Verteidigung gegen RNA- und DNA-Viren durch gezielten Abbau von kurzen doppelsträngigen Bereichen der entsprechenden RNA evolviert, werden auch andere als fremd erkannte RNAs abgebaut. Starke Überexpression eines zusätzlich eingebauten Gens lässt dieses als "fremd" erscheinen und induziert diesen Weg, Cosuppression. Abbildung $\mathrm{C}$ zeigt, wie die zu starke Aktivität eines zusätzlich eingebrachten Gens für die Chalconsynthase durch Cosuppression zur Unterbrechung der Anthocyansynthese und damit zu weißen Blütenblättern führt. Dabei induziert die hohe Menge an ChalconsynthasemRNA den RNAi-Apparat, der die mRNA abbaut. Chalconsynthase ist ein Schlüsselenzym der Anthocyanbiosynthese ( $\rightarrow$ Abbildung 16.5). Links: Wildtypblüte. Mitte: Blüte einer transgenen Pflanze mit Bereichen stillgelegter Chalconsynthase-Bildung. Rechts: Vollständige Unterdrückung der Chalconsynthase-mRNA führt zu ungefärbten Blüten. (Nach Kuhlmann und Nellen, 2004). Durch Einbringen kurzer RNA-Fragmente (auch als DNA mit starkem Promotor) lassen sich so ganz gezielt einzelne Gene herunterregulieren oder sogar abschalten.

Die Fähigkeit, Gene in Pflanzen stabil einzubauen, eröffnet darüber hinaus viele Möglichkeiten zur Veränderung ihrer physiologischen Eigenschaften. Beispielsweise können Stoffwechselwege eingeführt werden, die normalerweise in der Pflanze nicht vorkommen. Die hierzu benötigten Gene können von anderen Pflanzen oder auch von Bakterien oder Tieren stammen. Auf die Verwendung von transgenen Pflanzen als Bioreaktoren für die Produktion von nutzbaren Pflanzeninhaltsstoffen wird im Kapitel 28 näher eingegangen.

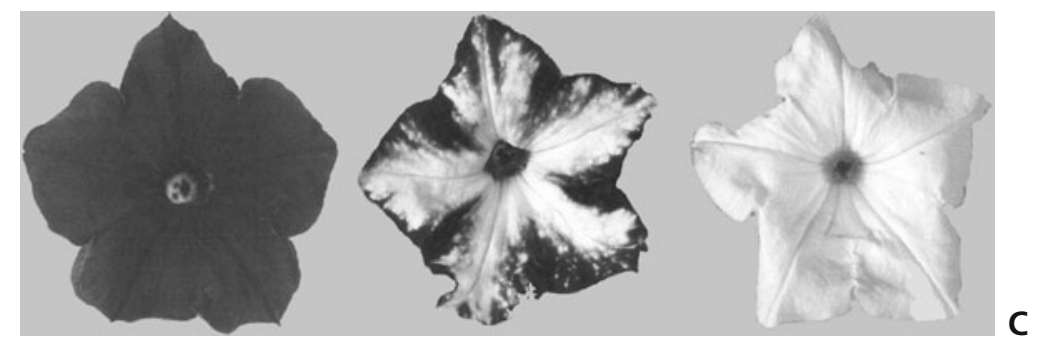

dieser prokaryotischen Charakteristika sind auch die Promotoren, die dieses Enzym erkennt, ähnlich wie bakterielle Promotoren aufgebaut (Abbildung 6.11). Die dazugehörigen Transkriptionsfaktoren (Sigmafaktoren) sind jedoch im Kerngenom codiert und werden in die Plastiden importiert. Die Existenz einer zweiten RNA-Polymerase in den Plastiden wurde bei Gerstenmutanten gezeigt, in denen wegen des Ausfalls eines ribosomalen Proteins in den Plastiden keine funktionsfähigen Ribosomen entstehen. Obwohl diese Plastiden keine Proteine, also auch keine plastidencodierte RNAPolymerase, bilden können, enthalten sie Transkripte verschiedener Plastidengene. Dafür ist eine kerncodierte RNA-Polymerase verantwortlich, die aus dem Cytoplasma importiert wird. Die große 
Ähnlichkeit dieses Proteins und des entsprechenden Gens mit der RNA-Polymerase für die Mitochondrien zeigt, dass das Gen für die Plastidenform durch Duplikation entstanden ist. Die Verwandtschaft mit RNA-Polymerasen in Bakteriophagen wiederum belegt die prokaryotische Herkunft des Gens. Dieses Enzym transkribiert u.a. auch die Gene für die plastidencodierte RNA-Polymerase.

Die wie bei Prokaryoten in Gruppen eng beieinanderliegenden Gene des Plastidengenoms werden häufig in polycistronische mRNAs umgeschrieben, die anschließend in monocistronische Transkripte zerlegt werden ( $\rightarrow$ Abbildung 6.7). In den plastidären Operons können auch Gene für Proteine verschiedener Funktionen zusammengefasst sein; z. B. für das Chlorophyll-Apoprotein CP47, das 10-kDaPhosphoprotein des Photosystems II und eine Untereinheit des Cytochrom- $b / f-$ Komplexes $(\rightarrow$ S. 183).

Wie die Kerngene sind auch viele Plastidengene durch Introns unterbrochen, die als prokaryotische Introns der Gruppen I und II klassifiziert werden. Zur Entfernung dieser Introns aus den Transkripten werden Proteinfaktoren benötigt, die meist kerncodiert sind und in die Plastide importiert werden müssen. Beim Gen für das ribosomale Protein S12 hat man gefunden, dass zwei der drei Exons weit voneinander entfernt und in umgekehrter Orientierung auf der Plastiden-DNA liegen; das Leseraster für das Protein kann also nicht durchgehend auf einem pre-mRNA Molekül lokalisiert sein. Die zusammengehörenden Exons werden in diesem Fall durch trans-splicing aus verschiedenen Primärtranskripten zusammengefügt. Die Erkennung erfolgt dabei über die an die Exons angrenzenden Abschnitte der Gruppe-II-Introns, die sich zusammenlegen und so die passenden Exonenden miteinander in Kontakt bringen können $(\rightarrow$ Abbildung 6.1).

Wie in allen prokaryotischen Organismen bleiben auch in den Plastiden die mRNAs ohne Capund Poly(A)-Strukturen. Die Transkripte werden vielmehr durch Haarnadelstrukturen am 3'-Ende stabilisiert, die durch RNA-bindende Proteine erkannt werden. Die dort gebildeten RNA-Proteinkomplexe dienen als Marker für die Prozessierung und verhindern gleichzeitig das weitere Fortschreiten des RNA-Abbaus durch Exonucleasen. Teilweise leitet ganz ähnlich wie bei Bakterien das An-

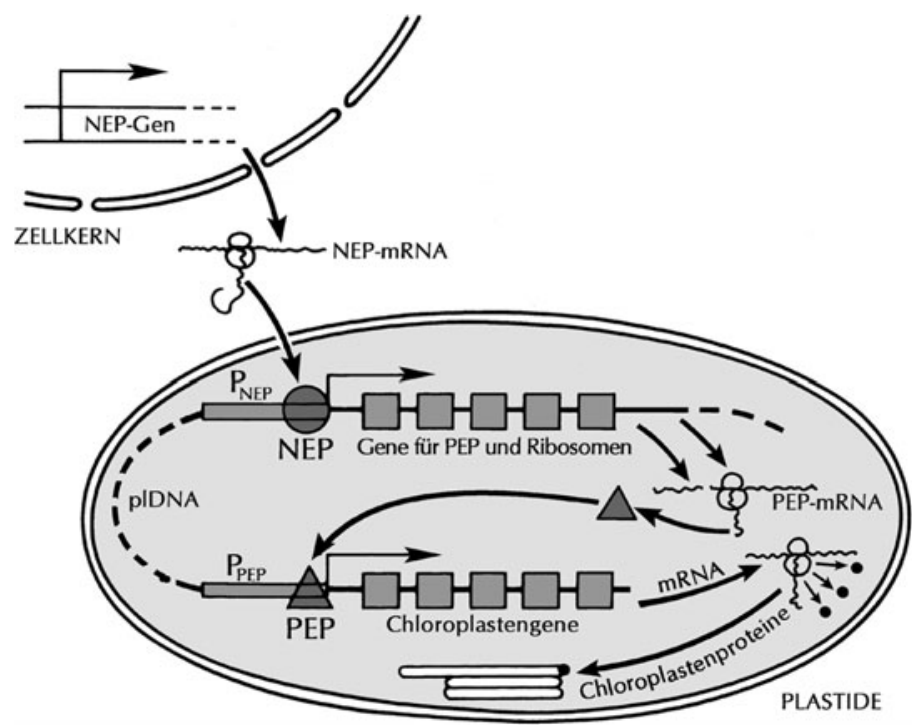

Abb. 6.11. Die Gene in der Plastiden-DNA werden von zwei verschiedenen RNA-Polymerasen abgelesen. Der im Kern codierte Typ ist eine Phagen-ähnliche Polymerase (NEP = nuclear encoded polymerase), die andere ist Bakterien-ähnlich und zu einem großen Teil im Plastidengenom codiert ( $P E P=$ plastid encoded polymerase). Wie bei Bakterien besteht die PEP aus mehreren Untereinheiten, während die NEP nur aus einem Protein besteht. Zuerst wird die NEP an cytoplasmatischen Ribosomen synthetisiert und in die Plastiden transportiert. Dort transkribiert sie die Gene für PEP, ribosomale Proteine und rRNAs vermittelt von spezifischen Promotoren $\left(P_{N E P}\right)$. Die PEP liest die Gene für die Photosynthese mit ihren PEP-Promotoren $\left(P_{P E P}\right)$ ab und synthetisiert die mRNAs, die in den Plastiden translatiert werden können. Dadurch übt der Zellkern die Hauptkontrolle über das Genom in den Plastiden schon bei der Synthese der plastidären mRNA aus. 
fügen von Oligo(A) an das 3'-Ende den Abbau dieser Moleküle ein.

Zwischen 20 und 40 Nucleotide in den mRNAs der Plastiden von Samenpflanzen stimmen nicht mit den genomisch vorgegebenen Codons überein. So wird während der RNA-Reifung z. B. ACG zum translationsinitierenden AUG abgewandelt. Dieses Phänomen nennt man RNA-editing. Es führt dazu, dass in verschiedenen Genen einige genomisch vorhergesagte, und auch bei der Transkription in die RNA eingebaute, Cytosine in Uridine abgeändert werden.

\subsubsection{Transkription mitochondrialer Gene}

Obwohl in den Mitochondrien die einzelnen Gene auf der DNA meist sehr viel weiter voneinander entfernt liegen als in den Plastiden, werden auch hier einige Gengruppen in polycistronische mRNAs umgeschrieben, wobei ebenfalls funktionell komplexe Transkripte resultieren. In pflanzlichen Mitochondrien wurden zwei verschiedene Promotortypen gefunden, von denen einer eine stark konservierte, der andere eine relativ variable Struktur hat. Die mitochondriale RNA-Polymerase ist mit der kerncodierten plastidären RNA-Polymerase verwandt und muss aus dem Cytoplasma importiert werden. Bei der Reifung mitochondrialer mRNAs werden Introns entfernt und die Exons, $u$. U. durch trans-splicing, zum funktionsfähigen RNA-Molekül zusammengefügt. Beispielsweise entstehen mRNAs für einzelne Untereinheiten der Atmungskettenkomplexe aus Fragmenten, die in drei verschiedenen Genomregionen codiert sind. Mit dieser räumlichen Aufgliederung von Genteilen in der DNA verschwimmt auch die molekulare Definition des Gens, da die zusammenhängende genetische Information für ein Protein eigentlich erst auf der RNA-Ebene vorliegt.

\subsubsection{RNA-editing}

Das bei Plastiden selten beobachtete posttranskriptionale editing der RNA, d. h. die sekundäre Umwandlung von Cytosin in Uridin (oder umgekehrt) in RNA-Molekülen, ist in Mitochondrien höherer Pflanzen sehr viel stärker ausgeprägt. Hier kann kein einziges proteincodierendes Gen ohne massives editing seiner mRNA in ein funktionsfähiges Protein übersetzt werden.
Diese Veränderungen der RNA-Sequenz gegenüber der DNA-Sequenz können in Einzelfällen bis zu $20 \%$ der Codons, und damit der Aminosäuren im Protein, betreffen. In den Mitochondrien höherer Pflanzen sind insgesamt 400-500 editingSchritte erforderlich, um die RNA in die funktionell korrekte Form zu bringen. Die Auswahl der zu verändernden Cytosine erfolgt über spezifische RNA-Bindung durch einzelne PPR-Proteine. Die etwa 450 PPR-Proteine (Pentatrico-Peptide-Repeat-Proteine) der Blütenpflanzen enthalten mehrere Kopien eines 35-Aminosäuren-Motivs und sind an vielen RNA-Reifungsprozessen wie Intron-splicing und RNA-editing in Plastiden und Mitochondrien beteiligt. Möglicherweise wird durch das RNA-editing eine weitere Kontroll- und Korrekturebene in die Genexpression eingeführt. Dafür spricht z.B. der Befund, dass einige tRNAs erst nach editing aus der pre-tRNA herausgeschnitten werden können. Auch manche Introns lassen sich erst nach editing durch Basenpaarung zu der Sekundärstruktur falten, die ein Herausschneiden ermöglicht.

Welche Enzyme an der Umwandlung des Cytosins zum Uridin in der RNA-Kette beteiligt sind, ist noch unklar. Dieser Mechanismus ist dort, wo er vorkommt, notwendig für die korrekte Genexpression. Andererseits konnte er bei Bakterien und niederen Pflanzen (Grünalgen bis hin zu den Characeen, Lebermoosen) nicht nachgewiesen werden. Offenbar hat sich dieser Eingriff in den normalen Ablauf der Informationsübertragung vom Gen zum Protein erst bei der Evolution der Landpflanzen in den Mitochondrien und Plastiden etabliert.

\subsection{Proteinsynthese (Translation) und Protein-turnover}

\subsubsection{Translation und Protein-turnover im Cytoplasma}

Die Synthese von Proteinen findet in den drei Zellkompartimenten Cytoplasma, Plastiden und $\mathrm{Mi}$ tochondrien statt. Die Mechanismen der Translation im Cytoplasma sind bei allen Eukaryoten sehr ähnlich, während sie in den Plastiden und Mitochondrien abweichen und auch zwischen diesen beiden Kompartimenten prokaryotischen Ursprungs Unterschiede aufweisen. Mit wenigen Ausnahmen wird in allen drei genetischen Systemen der Pflanzenzelle der gleiche Code für die Um- 
schreibung der RNA-Basensequenz in die Aminosäuresequenz der Proteine verwendet, wie er auch in allen anderen Bereichen der Lebewesen von den Bakterien bis zum Menschen gültig ist. Lediglich in einigen Algengruppen hat man kleinere Abweichungen von diesem „universellen“ Code gefunden, z. B. codiert in den Mitochondrien der Rotalge Chondrus crispus TGA nicht, wie sonst üblich, für ein Stopcodon, sondern für die Aminosäure Tryptophan.

Die cytoplasmatischen Ribosomen (80S) enthalten die vier klassischen ribosomalen RNAs (25S, $18 \mathrm{~S}, 5,8 \mathrm{~S}$ und $5,5 \mathrm{~S}$ ), von denen die ersten drei in einem Operon codiert sind. Diese rRNAs werden durch etwa 70 Proteine zu einem kompakten, aus zwei Untereinheiten (60S, 40S) bestehenden, etwa $20 \mathrm{~nm}$ großen Partikel komplexiert, das im Elektronenmikroskop leicht zu identifizieren ist, insbesondere, wenn mehrere Ribosomen in Form eines Polysoms mit einer mRNA assoziiert sind ( $\rightarrow$ Abbildung 2.4). Normalerweise wird die Größe dieser Partikel durch ihre Sedimentationsgeschwindigkeit (S-Werte) charakterisiert. Für die Bindung der mRNA an das Ribosom und die Initiation und Elongation des entstehenden Proteins ist neben den Aminosäure-spezifischen tRNAs eine Vielzahl von Proteinen erforderlich. Dazu gehören z. B. das Capbindende Protein und das Poly(A)-bindende Protein, die als Initiationsfaktoren fungieren. Viele dieser Translationsfaktoren sind auch bei Pflanzen identifiziert; es handelt sich meist um Homologe der entsprechenden tierischen und pilzlichen Proteine, die gegenüber diesen ein hohes Maß an Konservierung aufweisen (Abbildung 6.12). Pflanzenviren nutzen die Translationsmaschinerie aus, um unter Benützung viruseigener und pflanzeneigener Translationsfaktoren extrem hohe Proteinsyntheseraten zu induzieren. Die genomische RNA des Tabakmosaikvirus enthält zwar eine Cap-Struktur am $5^{\prime}$-Ende, an die zelluläre Proteine gebunden werden können, aber keine Poly(A)-Kette am 3'-Ende, das zu einer Kleeblatt-artigen Struktur gefaltet ist (Abbildung 6.13). An dieser Stelle binden spezifische Proteine, die den Zugang zum Ribosom und die Interaktion mit den anderen Initiations- und Elongationsfaktoren herstellen.

Die neu synthetisierten Proteine durchlaufen in der Regel diverse Schritte der Reifung, Faltung, Zusammenlagerung und chemischen Modifikation bis die voll aktive Struktur erreicht ist. Neben solchen Modifizierungen dient die Kontrolle über die
Lebensdauer der Proteine zur Regulation ihrer Aktivität $(\rightarrow$ S. 92). Insbesondere Proteine mit regulatorischen Aufgaben, z. B. Transkriptionsfaktoren, sind durch einen relativ hohen turnover ausgezeichnet, wodurch eine rasche Reaktion auf Steuersignale ermöglicht wird. Außerdem können auf diese Weise defekte Proteine eliminiert werden. Im Cytoplasma und im Zellkern wird der proteolytische Abbau eines Proteinmoleküls durch Verknüpfung mit Ubiquitin, einem Polypeptid von $8,5 \mathrm{kDa}$ eingeleitet ( $\rightarrow$ S. 93).

\subsubsection{Translation und Protein-turnover in Plastiden}

Der Translationsapparat der Plastiden ist deutlich prokaryotischer Herkunft. Sowohl die ribosomalen RNAs (23S, 16S, 5 S und 4,5S), als auch die diversen ribosomalen Proteine, zeigen in ihren primären Sequenzen eine hohe Ähnlichkeit mit den homologen Molekülen in Bakterien. Dies gilt auch für die an der Translation beteiligten Proteine. Die plastidären Ribosomen (70S) bestehen wie die der Bakterien aus einer 50S- und einer 30S-Untereinheit. Bei den meisten plastidären proteincodierenden Genen findet sich eine klassische prokaryotische Ribosomenbindungssequenz 10-20 Nucleotide vor dem ersten translatierten AUG-Codon. Diese Sequenz ist komplementär zur Sequenz am 3'-Ende der 16S-rRNA und ist an der Bindung und Erkennung zwischen mRNA und Ribosom beteiligt. Mehrere ribosomale Proteine in den Plastiden sind nicht mehr die ursprünglich mit dem Endosymbionten eingewanderten Moleküle, sondern wurden im Laufe der Evolution durch Proteine aus der Wirtszelle ersetzt. Das jeweils entsprechende Gen wurde im Zellkern dupliziert, so dass heute je ein Gen für das cytoplasmatische und das plastidäre Protein codieren. Viele der mRNAs in den Plastiden sind nicht mit Ribosomen assoziiert, sondern werden durch RNA-bindende Proteine stabilisiert. Wie in Bakterien werden auch in den Plastiden freie RNAs sehr viel schneller abgebaut als bei der Translation aktive mRNAs.

In photosynthetisch aktiven Geweben enthalten die Chloroplasten bis zu 50 \% der gesamten Proteinmenge der Zelle. Da durch die photochemischen Prozesse und die damit einhergehende Bildung agressiver Sauerstoff-Spezies Proteine geschädigt werden können $(\rightarrow$ S. 601), ist ein effizienter Mechanismus für den Abbau von defekten Prote- 


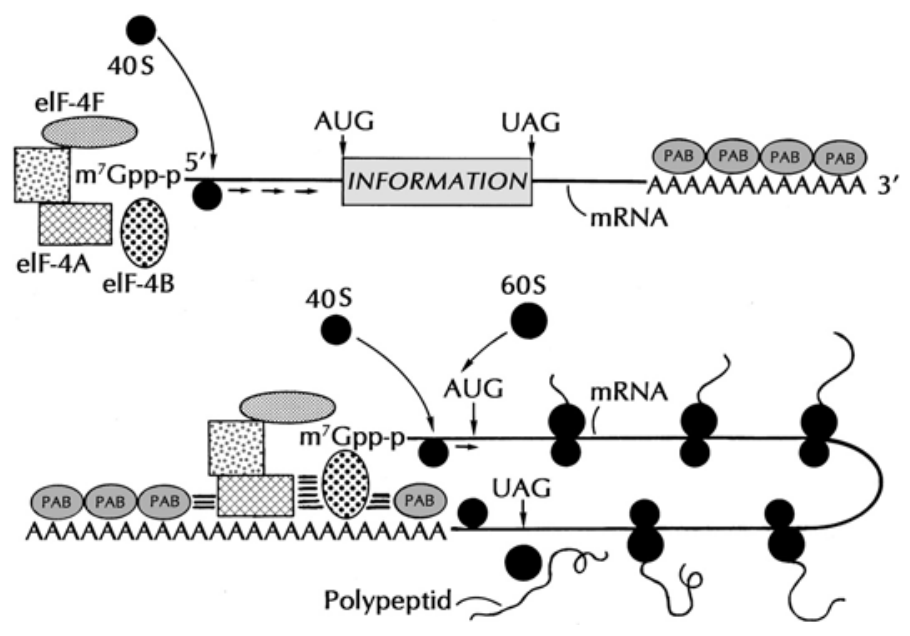

Abb. 6.12. Schematische Übersicht über die wichtigsten Teilprozesse der Translation durch cytoplasmatische Ribosomen und die daran beteiligten Proteinfaktoren (vergrößert dargestellt). Oben: Bei der Initiation wird eine 40S-Ribosomenuntereinheit an das $5^{\prime}$-Ende der mRNA ( $\left.C a p=m^{7} G p p\right)$ gebunden, ebenso verschiedene Elongationsfaktoren (elF). Das Poly(A)-bindende Protein (PAB) lagert sich an den Poly(A)-Schwanz am 3'-Ende der mRNA an. Die 40S-Untereinheit wandert an der mRNA entlang, bis sie das Initiationscodon (AUG) gefunden hat. Unten: Während der Translation bildet die mRNA eine Schleife, die durch multiple Wechselwirkungen zwischen mRNA, PAB- und elF-Proteinen stabilisiert wird. Die Translation startet, nachdem auch die ribosomale 60S-Untereinheit assoziiert ist. Dabei werden die durch ihre spezifischen tRNAs gebundenen Aminosäurereste nach Maßgabe des mRNA-Codes verknüpft. Beim Erreichen des Stopcodons (UAG) dissoziieren die ribosomalen Untereinheiten von der mRNA ab, entlassen die neu synthetisierte Polypeptidkette und stehen für die nächste Runde der Translation zur Verfügung. An einem mRNA-Molekül können bis zu 10 Ribosomen gleichzeitig translatieren. (Nach Gallie 1996, verändert)

inen erforderlich. Einige der aufgeklärten plastidären Proteinasen sind Homologe bakterieller Enzyme. Der wichtigste plastidäre Proteinasekomplex besteht aus einer Serinproteinase und einer ATPase, die unter ATP-Hydrolyse Proteinsubstrate entfalten und abbauen können. Beide Proteine bzw. ihre Gensequenzen wurden in einer Vielzahl von Pflanzen identifiziert. Die Proteinase und die meisten ATPase-Untereinheiten sind im Plastidengenom codiert; lediglich für eine ATPase-Untereinheit liegt die genetische Information im Kerngenom. Das an cytoplasmatischen Ribosomen synthetisierte Protein wird in die Chloroplasten importiert. Auch die verschiedenen anderen plastidären Proteinasen sind kerncodiert, wobei allerdings Gene für einzelne Cofaktoren auch im Plastidengenom liegen können.

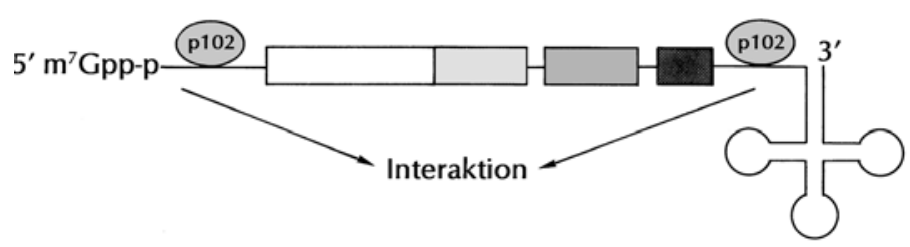

Abb. 6.13. Struktur der genomischen RNA (mRNA) des Tabakmosaikvirus (TMV). Viren benutzen zur effizienten Translation ihrer genetischen Information teils viruseigene, teils zelluläre Cofaktoren. Beim TMV bindet das viruseigene $p 102-$ Protein an die RNA und vermittelt die Anheftung an das Ribosom und die Initiation der Translation der Virus-RNA. Diese ist am $5^{\prime}$-Ende mit einer Cap-Struktur $\left(m^{7} G p p\right)$ versehen, so dass das Cap-bindende Protein dieses Ende erkennen kann. Am 3'-Ende besitzt die RNA an Stelle eines Poly(A)-Schwanzes eine tRNA-ähnliche Struktur, die sich in mehrere Pseudoknoten auffalten kann und von dem p102-Protein zur Erkennung genutzt wird. Die Translation dieser RNA ist von der Interaktion der beiden Enden abhängig ( $\rightarrow$ Abb. 6.12). (Nach Gallie 1996) 


\subsubsection{Translation und Protein-turnover in Mitochondrien}

Auch die Mitochondrien besitzen ihre eigenen Wege für die Synthese und den Abbau von Proteinen. Für die Translation werden auch hier prokaryotische Mechanismen vermutet. Bei Mitochondrien ist es bisher nicht gelungen, ein in-vitro-Translationssystem zu entwickeln, so dass die direkte Analyse der beteiligten Signal- und Steuerfaktoren noch aussteht. Die Ribosomen (78S) der Mitochondrien sind prokaryotischer Natur. Sie zeigen in den Primärsequenzen der rRNA und der ribosomalen Proteine eine eindeutige Ähnlichkeit mit den Entwicklungslinien der $\alpha$-Purpurbakterien. Die ribosomalen RNAs von Mitochondrien sind mit 26S, $18 \mathrm{~S}$ und 5S deutlich größer als die der Plastiden. Die zusätzlichen Sequenzen liegen in den nichtkonservierten, peripheren Regionen dieser Moleküle, unterscheiden sich aber von den typischen eukaryotischen Insertionen hinsichtlich Primärsequenz und damit Herkunft. Nur wenige ribosomale Proteine sind im mitochondrialen Genom codiert, während die überwiegende Zahl der proteincodierenden Gene im Laufe der Evolution in das Kerngenom abgewandert ist ( $\rightarrow$ Abbildung 6.8).

Auch in den Mitochondrien wird der Abbau von Proteinen durch spezifische Proteinasen katalysiert, die sich in ihrer evolutionären Herkunft und Spezifität eindeutig von den cytoplasmatischen und plastidären Proteinasen unterscheiden, aber noch nicht alle charakterisiert sind.

\subsection{Die Zelle als regulatorisches Netzwerk der Genexpression}

\subsubsection{Regulation nucleärer Gene}

Das genetische Programm, das in den DNAs in Zellkernen, Plastiden und Mitochondrien gespeichert ist, muss entsprechend der inneren und äußeren Anforderungen abgerufen werden. So müssen in verschiedenen Entwicklungsstadien bzw. in verschiedenen Zellen zur spezifischen Ausbildung einzelner Funktionen teilweise unterschiedliche Syntheseleistungen vollbracht werden, die unterschiedliche Enzyme benötigen und daher eine unterschiedliche Expression von Genen bedingen. Hierbei ist es erforderlich, die genetischen Leistungen der drei gentragenden Zellkompartimente präzise aufeinander abzustimmen. Die zentrale Kontrolle der Genexpression geht vom Zellkern aus, in dem nicht nur die meisten Strukturgene, sondern auch regulatorische Informationen lokalisiert sind und kontrolliert abgelesen werden können. Darüber hinaus gibt es im Verlauf der Umsetzung genetischer Information in die Sequenz der Aminosäuren in einem Protein viele weitere Teilprozesse, an denen durch bestimmte Faktoren regulierend eingegriffen werden kann (Abbildung 6.14).

Eine generelle Steuerungsmöglichkeit für die Ablesung der Gene liegt bei der Verpackung der DNA $(\rightarrow$ Abbildung 6.3). Durch eine engere Aufwindung und einen gedrängteren Besatz mit Proteinen kann der Zutritt der RNA-Polymerasen zur DNA behin-

Tabelle 6.4. Zusammenstellung einiger unterschiedlicher Charakteristika zwischen Genexpressionssystemen prokaryotischer (Bakterien, Plastiden, Mitochondrien) und eukaryotischer (Zellkern) Evolutionslinien.

\begin{tabular}{|c|c|c|}
\hline & Bakterien, Plastiden, Mitochondrien & Zellkern \\
\hline Genome & $\begin{array}{l}\text { polyploid, wenig eingepackt, } \\
\text { an Membran gebunden }\end{array}$ & $\begin{array}{l}\text { haploid/diploid, linear, } \\
\text { in Chromosomen verpackt }\end{array}$ \\
\hline Gene & $\begin{array}{l}\text { Introns Typ II oder/und I, } \\
\text { oft polycistronisch, } \\
\text { transsplicing }\end{array}$ & $\begin{array}{l}\text { Introns erfordern Spliceosomen, } \\
\text { oft alternatives splicing, } \\
\text { meist monocistronisch }\end{array}$ \\
\hline Transkription & $\begin{array}{l}\text { bakterielle RNA-Polymerase } \\
\text { mit } \sigma \text {-Kofaktoren, } \\
\text { Phagen-RNA-Polymerase }\end{array}$ & $\begin{array}{l}\text { Kern-RNA-Polymerasen } \\
\text { getrennt für mRNA, rRNA, } \\
\text { tRNA }\end{array}$ \\
\hline Translation & $\begin{array}{l}\text { ähnliche rRNAs, keine } 5,8 \mathrm{~S}-\mathrm{rRNA} \text {, } \\
\text { charakteristische ribosomale } \\
\text { Proteine }\end{array}$ & $\begin{array}{l}\text { typisch vergrößerte rRNAs, } \\
5,8 S-r R N A \text {, eigene ribosomale } \\
\text { Proteine }\end{array}$ \\
\hline mRNA & $\begin{array}{l}\text { ohne Cap, PolyA destabilisiert, } \\
\text { RNA-editing }\end{array}$ & $\begin{array}{l}\text { mit Cap, PolyA stabilisiert, } \\
\text { Export aus Zellkern }\end{array}$ \\
\hline
\end{tabular}


dert, und damit ein Gen abgeschaltet werden. Für die Verpackungsdichte spielt die Aktivität von SARs (scaffold attachment regions), mit denen das DNAMolekül an das nucleäre Proteingerüst angeheftet wird, eine wichtige Rolle. Darüber hinaus können DNA-Regionen durch Methylierung von Basen in ihrer Transkriptionsfähigkeit verändert werden. Eine dichtere Methylierung kann in einer Region des Genoms eine Aktivierung, in einer anderen Region eine Inaktivierung bewirken. Auch bei Pflanzen wird wahrscheinlich die Stilllegung paralleler Allele des zweiten Chromosomensatzes durch großräumige Methylierungen ermöglicht. Unklar ist bisher, wie die DNA-Regionen für die Methylierung ausgewählt werden. Wird experimentell, z. B. in transgenen Arabidopsis-Pflanzen, die generelle Methylierung durch antisense-Hemmung der Cytosinmethyltransferase behindert, so stellen sich phänotypische Störungen der Entwicklung ein. Diese führen z. B. zu einer Verlängerung der vegetativen Wachstumsphase und der Blütenentwicklung (Abbildung 6.15; $\rightarrow$ Exkurs 6.7; S. 142).

Die spezifische Regulation einzelner Gene setzt meist an Promotor- bzw. enhancer-Elementen an $(\rightarrow$ Abbildung 6.1). Bei vielen Genen wird die Initiationsreaktion der Transkription als Schaltstelle für Ja/Nein-Entscheidungen benutzt. Durch gewebeund stadienspezifisch aktivierte Transkriptionsfaktoren werden z.B. die Gene für Speicherproteine angeschaltet. In allen anderen Geweben und Entwicklungsstadien sind diese Gene inaktiv. Für die Initiation der Transkription eines Gens wirken in der Regel mehrere Promotor- bzw. enhancer-Elemente orchesterartig zusammen. Die beteiligten enhancer-Elemente können sowohl vor, als auch hinter oder innerhalb der eigentlichen codierenden Regionen und dem Translationsinitiationspunkt liegen. Die an die enhancer-Elemente bindenden Transkriptionsfaktoren können durch geeignete Faltung der DNA auch dann mit dem Transkriptionsinitiationskomplex interagieren, wenn sie eine relativ weite Strecke entfernt an den DNAStrang binden.

Eine wichtige, bisher nur unbefriedigend beantwortbare Frage ist, wie die Transkriptionsfaktoren ihrerseits durch die auslösenden inneren oder äußeren Signale (z. B. Hormone, Licht) reguliert werden. In einer Reihe von Fällen hat sich gezeigt, dass diese Proteine nicht wiederum selbst auf der Ebene der Genexpression reguliert werden, sondern durch poststranslationale Modifikation (z. B. durch Phos-

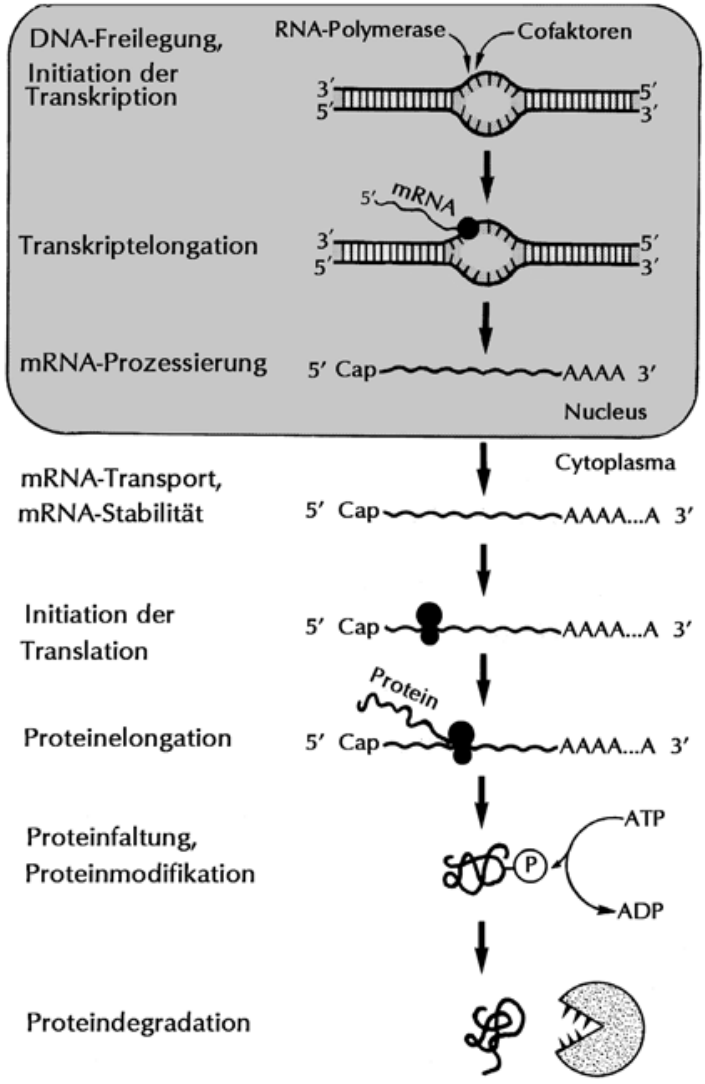

Abb. 6.14. Übersicht über die potenziellen Regulationsstellen bei der Genexpression. Dieses Schema zeigt die verschiedenen Angriffsmöglichkeiten für die Regulationsmechanismen bei der Umsetzung der Information von der DNA bis zum funktionsfähigen Protein. Im Einzelfall wird von diesen Regulationsmechanismen in unterschiedlicher Weise Gebrauch gemacht. Der wichtigste Regulationsschritt erfolgt bei der Initiation der Transkription durch die spezifischen Wechselwirkungen zwischen cis- und trans-Elementen im Promotorbereich des Gens $(\rightarrow$ Abbildung 6.9).

phorylierung) Veränderungen in ihrer Bindungsfähigkeit an die DNA erfahren. Auf jeden Fall muss man eine biochemische Signalkette postulieren, die mit der Aufnahme des Signals durch einen spezifischen Receptor (z. B. einen Photoreceptor für Lichtsignale) beginnt und über eine mehr oder minder große Zahl von Zwischengliedern zur Aktivierung oder Inaktivierung eines oder mehrerer Transkriptionsfaktoren führt. Mit Hilfe genetischer Methoden gelang es in den letzten Jahren, erste Beispiele für solche Signalketten zumindest bruchstückhaft aufzuklären und einzelne Glieder daraus biochemisch zu identifizieren ( $\rightarrow$ S. 437-443). Da- 
bei hat sich gezeigt, dass diese Signalketten kaskadenartig angeordnete Verstärkerstufen enthalten können, über die ein schwaches Eingangssignal vergrößert wird, bevor es auf der Genebene zur Wir- kung kommt. Dies erklärt die oft extrem hohe Empfindlichkeit der Pflanze für Signale aus der Umwelt, z. B. für Licht.

EXKURS 6.7: Weshalb ist Arabidopsis eine bevorzugte Modellpflanze der genphysiologischen Forschung?

Arabidopsis thaliana (Ackerschmalwand, Brassicaceae) ist ein unscheinbares Ackerunkraut, das in wenigen Jahren zum dominierenden Objekt der molekularbiologischen und entwicklungsphysiologischen Forschung an höheren Pflanzen geworden ist. Dies hat verschiedene Gründe:

>Arabidopsis ist ein repräsentativer Vertreter der höheren Pflanzen, an dem sehr viele physiologische Eigenschaften dieser Organismengruppe studiert worden sind und weiter analysiert werden können.

- Arabidopsis besitzt eines der kleinsten bisher bei Pflanzen bekannten Kerngenome ( 25.498 Gene) mit etwa $120 \mathrm{MB}$ bzw. 0,15 pg DNA in 5 Chromosomen des haploiden Satzes, was vor allem auf das geringe Vorkommen repetitiver Sequenzen zurückgeht $(\rightarrow$ S. 124). Hierdurch wird der experimentelle Aufwand für genetische Mutantenanalysen und die molekularbiologische Identifizierung von Genen relativ gering gehalten. Solche Untersuchungen sind durch die vollständige Sequenzanalyse des Arabidopsis-Genoms erheblich erleichtert worden.

$>$ Die Gesamtheit der bekannten und potenziellen Gene von Arabidopsis ist auf sogenannten Genchips verfügbar, mit denen Aktivitätsänderungen einzelner Gene bei verschiedenen Bedingungen untersucht werden können.

$>$ Weltweit verfügbare Kollektionen von Mutanten in fast allen Genen erleichtern die Funktionsanalysen neuer Gene.

$>$ Arabidopsis ist auch als blühende Pflanze relativ klein und kann einzeln auf Petrischalen oder in großen Zahlen auf begrenzter Gewächshausfläche angezogen werden.

- Arabidopsis besitzt eine sehr kurze Generationszeit von etwa 8 Wochen von der Samenkeimung bis zur Produktion reifer Samen. Genetische Analysen sind daher mit einem vergleichsweise geringen Zeitaufwand durchzuführen.

> Arabidopsis lässt sich sowohl im Samen- als auch Pollenstadium leicht mutagenisieren.

> Arabidopsis-Pollen werden nicht durch Wind übertragen; dies erleichtert die gezielte experimentelle Bestäubung. Die Pflanzen lassen sich leicht selbsten und besitzen eine hohe Reproduktionsrate (bis zu mehreren tausend Samen pro Pflanze).

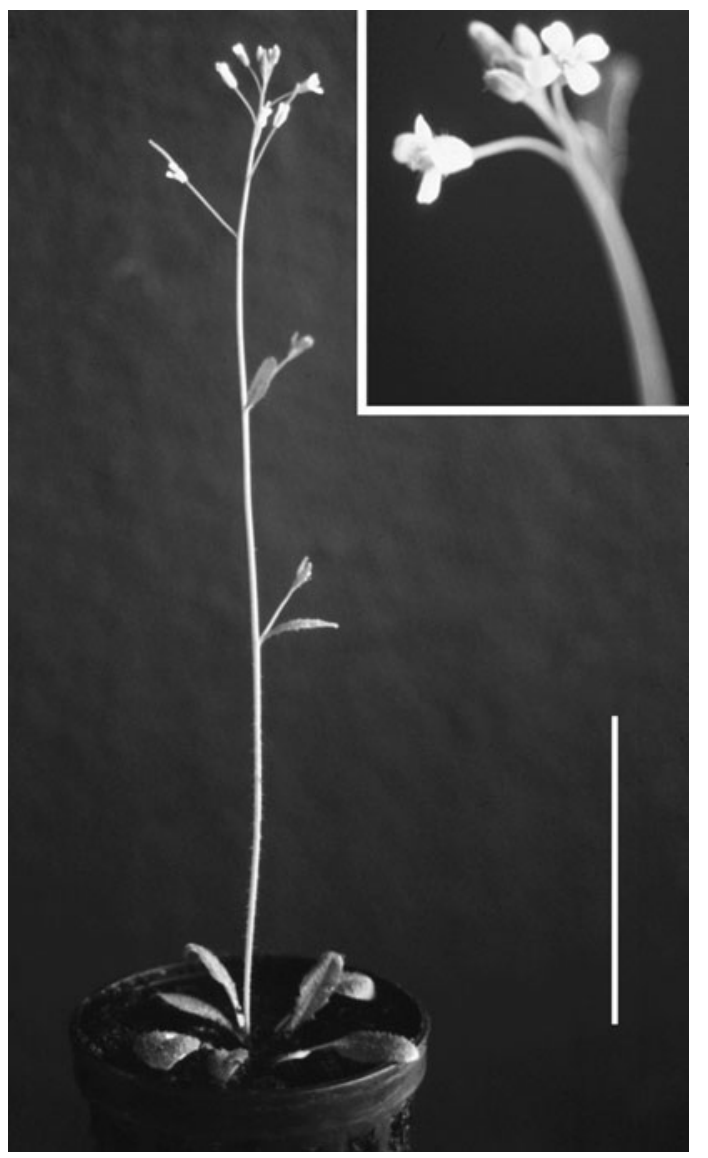

- Arabidopsis-Zellen bzw. -Pflanzen lassen sich leicht transformieren und anschließend zu transgenen Pflanzen regenerieren.

Die Kombination dieser Vorteile in einer Pflanze hat viele der jüngsten Fortschritte im Verständnis der genphysiologischen Grundlagen der pflanzlichen Entwicklung erst möglich gemacht. Daher wird auch in diesem und den folgenden Kapiteln oft auf Experimente mit Arabidopsis Bezug genommen. Die Abbildung zeigt eine 3 Wochen alte Arabidopsis-Pflanze, bei der in der untersten Blüte bereits das Fruchtwachstum eingesetzt hat. (Strich: $5 \mathrm{~cm}$ ) 

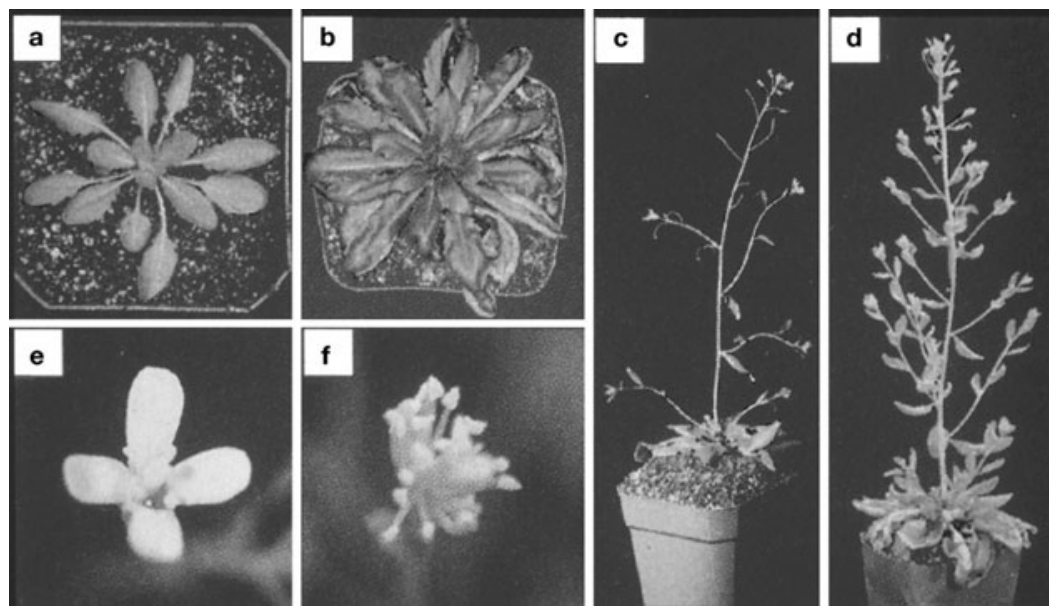

Abb. 6.15 a-f. Bedeutung der DNA-Methylierung für die Steuerung der Genaktivität. Die Methylierung von Basen in der DNA in bestimmten Bereichen des Kerngenoms ist für die normale Entwicklung der Pflanze wichtig. In diesem Experiment wurde die DNA-Methylierung im Kerngenom von Arabidopsis thaliana durch antisense-Unterdrückung des Enzyms Cytosinmethyltransferase gestört. Bei dieser Methode wird das fragliche Gen hinter einem in allen Zellen (konstitutiv) aktiven Promotor, z. B. dem 35S-Promotor des Blumenkohlmosaikvirus, in transgenen Pflanzen in umgekehrter Richtung zur Expression gebracht und damit das endogene Gen an der Expression gehindert $(\rightarrow$ S. 665). Dies führt hier zu massiven Entwicklungsstörungen in den transgenen Pflanzen (b, d, f) gegenüber dem Wildtyp (a, c, e), die jedoch keine direkten Hinweise auf die Natur der beteiligten Gene oder die Spezifität der DNA-Methylierung bei der Beeinflussung der Transkription liefern. (Nach Ronemus et al. 1996)

Die biochemische Aufklärung der auf der Ebene der Genregulation mündenden Signaltransduktionsketten ist ein derzeit besonders intensiv verfolgtes Forschungsziel. Eine Methode für die Identifizierung der cis-Elemente, die bei der Steuerung eines Gens beteiligt sind, ist die Deletionsanalyse (Abbildung 6.16). Die auf diese Weise gefundenen regulatorisch wirksamen DNA-Regionen können nun als Hybridisierungssonden verwendet werden, um die zugehörigen DNA-bindenden Proteine zu isolieren und deren Gene aufzuspüren. Auf diese Weise wurden bereits zahlreiche derartige Proteine charakterisiert, die oft auch in homologer Form in tierischen Organismen als Transkriptionsfaktoren bekannt sind.

Die spezifische Modulation der Promotoraktivität ist die vielleicht wichtigste, aber nicht die einzige Form der Kontrolle über die Genexpression, die die Gesamtheit der Prozesse von der Transkription der DNA bis zur Produktion der funktionsfähigen Proteine umfasst ( $\rightarrow$ Abbildung 6.14). So können z. B. auch Introns, obwohl sie keine ablesbare Information tragen und aus der RNA herausgeschnitten werden, einen erheblichen Einfluss auf die Transkription und die Menge bzw. Stabilität der gebildeten mRNA ausüben. Künstlich in ein Gen eingefügte Introns haben erstaunlicherweise meist eine positive Wirkung auf die Genexpression. Entfernt man z. B. bei Mais aus einem Gen für die Alkoholdehydrogenase das erste Intron, so wird die Expression stark gehemmt. Der zusätzliche Einbau dieses Introns in andere Gene steigert deren Expression um den Faktor 100. Auch in anderen Fällen konnte gezeigt werden, dass Intronsequenzen enhancer-Elemente enthalten können.

Für die Stabilität, und damit die Menge der mRNA, die für die Translation zur Verfügung steht, sind Sequenzabschnitte in der 3' -Region der Transkripte wichtig, durch die die Polyadenylierung [Anknüpfung einer Poly(A)-Kette durch eine Poly(A)-Polymerase] gesteuert wird. Die Länge des Poly(A)-Schwanzes beeinflusst die Empfindlichkeit der mRNA gegenüber dem Abbau durch RNasen. Die bei Pflanzen in ihrer Länge variabler als bei Tieren und Pilzen aufgebauten Poly(A)-Ketten steuern also die Lebensdauer der mRNAs, die zwischen wenigen Minuten und vielen Stunden oder Tagen variieren kann.

Auch auf der Ebene der Translation gibt es mehrere Eingriffsmöglichkeiten für steuernde Faktoren, z. B. bei der Erkennung des Startcodons, bei der Geschwindigkeit oder dem Abbruch der 
Elongation der Polypeptidkette $(\rightarrow$ Abbildung 6.14). So kann z. B. die Translationsgeschwindigkeit eines Ribosoms zwischen weniger als 2 und mehr als 10 Aminosäureverknüpfungen pro Sekunde variieren.

Schließlich wird der Pegel an aktivem Protein, das Endprodukt der Genexpression, durch generell oder spezifisch angreifende Proteinasen reguliert, wodurch z. B. Enzyme eine definierte Lebensdauer in der Zelle haben. Diese kann zwischen wenigen Stunden und mehreren Tagen variieren $(\rightarrow$ S. 92).

Die Vielzahl an potenziellen Regulationsstellen bedeutet nicht, dass diese immer zur Steuerung der Genexpression benützt werden. Es ist vielmehr notwendig, im Einzelfall genau zu prüfen, welche Teilprozesse als geschwindigkeitsbestimmende Schritte wirksam sind, da nur dort eine wirksame Regulation angreift. Es wird auch klar, dass man z.B. durch einen experimentellen Eingriff in einen nicht-geschwindigkeitsbestimmenden Teilprozess den Gesamtprozess lahmlegen kann, ohne dass dadurch Hinweise zum Mechanismus der Regulation gegeben werden. Dies bereitet bei der Aufklärung der bei der Genexpression im Organismus tatsächlich wirksamen Regulationsmechanismen große Schwierigkeiten.

\subsubsection{Regulation plastidärer Gene}

Im Gegensatz zu Kerngenen, die normalerweise nur in wenigen aktiven Kopien vorliegen, sind die Plastidengene in der Zelle in viel größerer Zahl vorhanden, die zudem sehr schwanken kann. So nimmt die Zahl der Plastidengenome pro Zelle bei der Entwicklung der Chloroplasten aus Proplastiden stark zu. Diese Genamplifikation erfolgt parallel zur Volumenvergrößerung und Teilung der Plastiden und reflektiert den gesteigerten Bedarf an Plastidenproteinen. Dies bedeutet auch einen entsprechend höheren Bedarf an solchen Plastidenproteinen, die im Kern codiert sind und im Cytoplasma synthetisiert werden. Es ist offensichtlich, dass eine wechselseitige Abstimmung der Expression von Kern- und Plastidengenen erforderlich ist, insbesondere wenn sie für solche Proteine codieren, die in ganz bestimmten Mengenverhältnissen in den Plastiden benötigt werden. Die Wirksamkeit einer solchen Abstimmung, z. B. die Steuerung der Transkription von Kerngenen für Plastidenenzyme durch Faktoren aus den Plastiden, ist experimentell belegt, aber molekular noch nicht aufgeklärt. Der Redoxzustand in den Plastiden spielt eine wichtige a

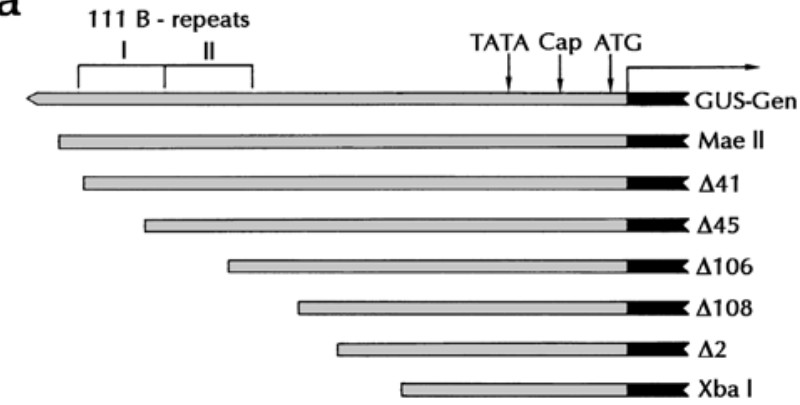

b

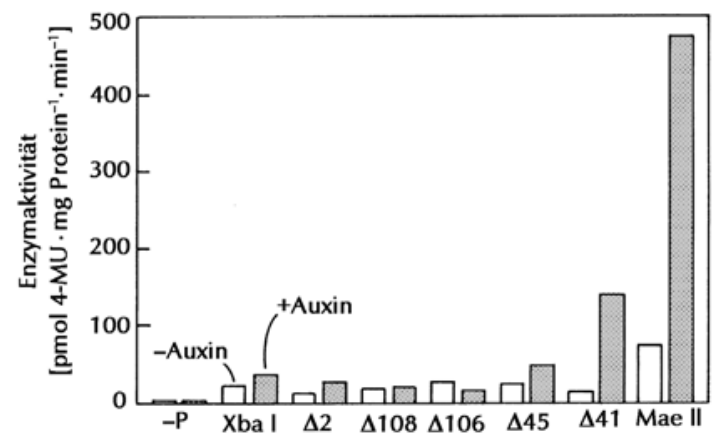

Abb. 6.16 a, b. Nachweis eines cis-Elements in der regulatorischen Sequenz (Promotorregion) eines auxininduzierbaren Gens (PAR-Gen). a Schematische Darstellung von chimären DNA-Konstrukten, die - eingebaut in eine Vektor-DNA - durch Elektroporation in Tabakprotoplasten eingeschleust wurden. Die Konstrukte bestehen aus der mehr oder minder stark verkürzten (deletierten) Promotorregion des PAR-Gens (helle Balken) und einem damit verknüpften Reportergen (dunkle Balken; GUS-Gen aus Escherichia coli, codiert für das Enzym $\beta$-Glucuronidase). Das längste Konstrukt (Mae II) besitzt eine Länge von 800 Basenpaaren (B). b Ausmaß der auxinabhängigen Expression des GUS-Gens in Protoplasten, in welche die verschieden stark deletierten Konstrukte eingeschleust wurden. Die enzymatische Aktivität der gebildeten GUS wurde anhand des Umsatzes von 4-Methylumbelliferon (4-MU) gemessen. $-P=$ GUSGen ohne Promotorregion. Es wird deutlich, dass die Auxinwirkung auf die Expression des GUSGens zum Erliegen kommt, wenn ein 111 B langes, wiederholtes Segment im Promotor fehlt oder unvollständig ist. Dies deutet darauf hin, dass in dieser Region ein Auxin-reguliertes cis-Element lokalisiert ist. (Nach Takahashi et al. 1990) 
Rolle als Signal, aber die Übertragungswege dieser Information zum Zellkern sind noch unklar.

Anders als im Zellkern hat die Transkriptionskontrolle durch den Promotor in Plastiden keine spezifische, sondern allenfalls eine generelle Funktion bei der Steuerung der Genexpression. Die wichtigere Kontrollstation liegt hier auf der Ebene der mRNA-Stabilität. Dies wird z. B. beim Vergleich der vorhandenen Transkriptmengen mit den Transkriptionsaktivitäten einzelner Gene deutlich (Abbildung 6.17). Die posttranskriptionale Regulation erfolgt durch einen kontrollierten Abbau der mRNAs. An den 3'-Enden der mRNAs binden genspezifisch verschiedene Proteinkomplexe, die RNAschützende Proteine oder RNasen enthalten. Über bestimmte Steuersignale, z.B. ausgelöst durch Licht, werden einzelne Komponenten dieser Kom-

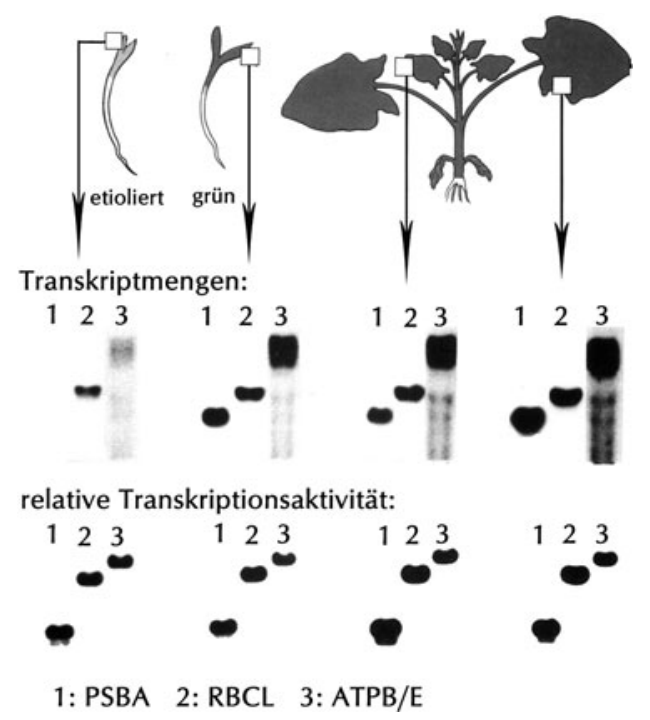

Abb. 6.17. Regulation der Genexpression in Plastiden über die Stabilität der mRNA. Während der verschiedenen Entwicklungsstadien der Plastiden in den Kotyledonen des etiolierten und des ergrünten Keimlings, bzw. in den jungen Folgeblättern von Bohnenpflanzen (Phaseolus vulgaris, (oben) liegen die mRNAs für drei verschiedene Gene $(1,2,3)$ in unterschiedlichen Mengen vor. Die relativen Transkriptmengen sind am Schwärzungsgrad der Flecken nach elektrophoretischer Auftrennung und Hybridisierung mit einer radioaktiven Sonde erkennbar, (Mitte). Die Transkriptionsaktivität, sichtbar gemacht als Einbau radioaktiver Vorstufen bei der Synthese der mRNAs, ist jedoch in allen Entwicklungsstadien gleich (unten). Die Unterschiede in den Transkriptmengen gehen also nicht auf unterschiedliche Promoteraktivitäten, sondern auf unterschiedlichen Abbau der mRNAs zurück. Die drei plastidären Gene codieren für die Untereinheit $A$ des Photoystems II (PSBA), die große Untereinheit der RUBISCO $(R B C L)$ und die Untereinheiten $\mathrm{B}$ und $\mathrm{E}$ der ATPSynthase (ATPB/E). (Nach Gruissem et al. 1988) plexe in ihrer Bindungsaktivität verändert und damit ein selektiver Abbau einzelner mRNAs ermöglicht. Der Vorteil dieser posttranskriptionalen Genregulation liegt vermutlich in der Schnelligkeit, mit der dieser Mechanismus auf Veränderungen in der Umwelt reagieren kann. Andererseits ist diese Form der Regulation mit einem hohen Aufwand an Syntheseleistung verbunden. Der hohe RNA-turnover in den Plastiden deutet darauf hin, dass energetische Rücksichtnahmen hier offenbar keine erhebliche Bedeutung besitzen.

Bei verschiedenen Plastiden-mRNAs hat man auch eine Beeinflussung der Genexpression über das Herausschneiden von Introns beobachtet. Prozessierungsaktivitäten, $z$. B. für die Entfernung von Introns aus Genen für Untereinheiten der ATPSynthase oder der Photosysteme, scheinen gewebespezifisch reguliert zu werden. In den Plastiden dunkel gehaltener, junger Keimlinge findet im allgemeinen die Prozessierung der mRNAs langsamer statt. Die Prozessierungsrate nimmt jedoch zu, wenn die Differenzierung zu Chloroplasten vorbereitet wird.

Für einige in der Plastiden-DNA codierten Gene ist auch eine translationale Kontrolle der Genexpression nachgewiesen worden. In der einzelligen Grünalge Chlamydomonas reinhardtii wird z. B. die Translationseffizienz über die Bindung von Aktivatorproteinen an spezifische mRNAs reguliert. Die Bindungsstärke dieser Proteine wird unter anderem über den Redoxstatus des Photosyntheseapparats gesteuert, der wiederum ein Indikator für die photosynthetische Aktivität der Chloroplasten ist $(\rightarrow$ S. 204). Die kerncodierten Aktivatorproteine interagieren mit der nicht-translatierten 5'-Region der mRNA und können dabei mit der Ribosomenbindungsstelle interagieren. Hierdurch wird der $\mathrm{Zu}$ gang des Ribosoms zur mRNA selektiv begünstigt.

Auch der Abbau von Proteinen ist an der Regulation der Genexpression in den Plastiden potentiell beteiligt. Untereinheiten verschiedener Proteinkomplexe werden proteolytisch abgebaut, wenn sie nicht in den Komplex integriert sind. So werden z. B. die kerncodierten kleinen Untereinheiten der RUBISCO nach ihrem Import in die Plastiden abgebaut, wenn sie nicht mit den in den Plastiden synthetisierten großen Untereinheiten verknüpft werden können. Auch defekte Moleküle, z. B. Cytochrome, denen der Cofaktor Eisen fehlt, unterliegen einem raschen Abbau durch plastidäre Proteinasen. 


\subsubsection{Regulation mitochondrialer Gene}

Wie im Zellkern und in den Plastiden können auch in den Mitochondrien viele Ebenen der Genexpression potenziell zur Regulation benutzt werden. Auch in diesen Organellen scheint die Zahl der Genomkopien zumindest in einem groben Rahmen an die Anforderungen der Zelle für mitochondriale Aktivität angepasst zu werden. So nimmt z. B. die mitochondriale DNA-Menge pro Zelle in einem wachsenden Meristem $\mathrm{zu}$, in einem ergrünenden Blatt aber bereits wieder ab. Unterschiedliche Promotoraktivitäten werden zwar bei einzelnen mitochondrialen Genen beobachtet; es scheint jedoch hier meist keine gewebespezifischen Unterschiede zu geben. Eine massive Aktivierung der gesamten mitochondrialen Genexpression ist während der Pollenreifung in den Tapetum- und Pollenmutterzellen der Antheren zu beobachten. In diesen Geweben ist aus bisher unbekannten Gründen eine extrem hohe Mitochondrienaktivität notwendig, um die Pollenreifung zu ermöglichen. Wie bei den Plastiden sind auch bei Mitochondrien die Transkriptmengen nicht mit den Transkriptionsaktivitäten korreliert. Dies lässt darauf schließen, dass auch hier posttranskriptionale Mechanismen an der Regulation der Genexpression beteiligt sind. Eine wie bei Plastiden bereits beschriebene Kontrolle über die Stabilität einzelner mRNAs durch Assoziation mit bestimmten Proteinen ist auch in Mitochondrien nachgewiesen. Desweiteren bietet das RNA-editing einen möglichen Ansatzpunkt für eine Regulation. Bei den bisher untersuchten Genen fand man allerdings nur kleinere Unterschiede im Ausmaß des editing, die mit gewebespezifischen Unterschieden in der mitochondrialen Aktivität in Zusammenhang zu bringen sind. Wenn auch halboder nicht-veränderte mRNAs in Proteine übersetzt werden, könnten sich diese Unterschiede allenfalls dort auswirken, wo die korrekte Aminosäuresequenz zum Tragen kommt, bei enzymatischen Aktivitäten oder beim Zusammenbau der Proteine zu Komplexen.

\subsubsection{Evolutionäre Adaption von Regulationsstrukturen}

Durch die endosymbiontische Aufnahme bakterieller Vorläufer, aus denen die heutigen Chloroplasten und Mitochondrien entstanden, wurden in die Pflanzenzelle in großem Umfang neue Informa- tionen eingebracht, die neue Mechanismen für die integrative Kontrolle bei ihrer Realisierung notwendig machten. Ein großer Teil der endosymbiontisch erworbenen Information wurde im Verlauf der Evolution in den Zellkern transferiert und den dort etablierten Kontrollmechanismen unterstellt. Vergleichende Analysen der mitochondrialen Genome verschiedener Spezies zeigen, dass die Translocation von Genen aus dem Organell in den Kern auch heute noch nicht abgeschlossen ist. Unterschiedlich weit gediehene Gentransfers aus den Mitochondrien in den Kern finden sich z. B. bei dem Lebermoos Marchantia, wo das für die Untereinheit 7 der NADH-Dehydrogenase (Komplex I der Atmungskette) codierende NAD7-Gen im mitochondrialen Genom noch als unvollständige, inkorrekt prozessierte und nicht-translatierbare RNA zu finden ist, während das aktive Gen im Zellkern liegt. Das Gen für die Untereinheit 2 der Cytochromoxidase (COX2) ist in der Sojabohne im mitochondrialen Genom vollständig, aber nicht transkribiert vorhanden; bei der Erbse ist dieses Gen aus den Mitochondrien ganz verschwunden (Abbildung 6.18). Bei beiden Pflanzen findet man dieses Gen in aktiver Form im Zellkern. Das Gen für die ribosomale Untereinheit S12 ist bei Mais, Weizen und Arabidopsis im mitochondrialen Genom codiert, während dort bei Oenothera nur noch ein kleines Fragment vorliegt. Das funktionale Gen sitzt bei Oenothera im Kern ( $\rightarrow$ Abbildung 6.8). Bei der Analyse solcher relativ junger Gentransfers in den Zellkern zeigte sich, dass Promotorstrukturen und die dazugehörigen Regulationsmechanismen im Kern so anpassungsfähig sind, dass sie durch Duplikation von anderen Genen übernommen oder aus normalerweise nicht aktiven DNA-Bereichen neu gebildet werden können. Die Modifikation genetischen Materials bei dem Transfer aus den Mitochondrien in den Zellkern beinhaltet unter anderem auch den Verlust des RNA-editing, das im Kern nicht beobachtet wird. Möglicherweise findet der Transfer in den Kern in Form von korrekt gereifter RNA statt, die im Kern zurück in DNA umgeschrieben wird. Zusätzlich findet man im Kern aber auch viele Fragmente der Plastiden- und Mitochondrien-DNAs mit organellentypischen Introns, die zwar redupliziert werden, aber keine erkennbare Funktion haben. Manche importierte DNA-Sequenzen haben auch eine funktionelle Umwidmung erfahren, z. B. ein 120 B langes mitochondriales Intronfragment, das bei Arabidopsis 


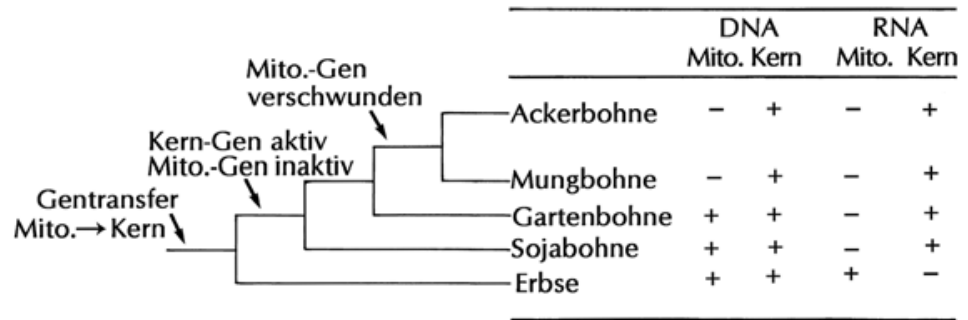

Abb. 6.18. Stadien auf dem Weg eines Gens aus dem Mitochondriengenom in das Kerngenom. Die Lokalisierung des Gens für die Untereinheit 2 des mitochondrialen Cytochromoxidasekomplexes (COX2) und seine Transkription wurde bei einzelnen Vertretern der Fabaceen vergleichend untersucht. Dieses Gen ist bei der Erbse (Pisum sativum) noch in den Mitochondrien in aktiver Form, aber auch bereits im Kern in inaktiver Form vorhanden. In der Sojabohne (Glycine max) und der Gartenbohne (Phaseolus vulgaris) sind ebenfalls beide Gentypen vorhanden, aber nur dasjenige im Kern wird transkribiert. In der Ackerbohne (Vicia faba) und der Mungbohne (Vigna radiata) liegt nur noch im Kern eine aktive Genkopie vor. (Nach Nugent und Palmer 1991)

Promotorfunktionen im Kern übernommen hat. Auch an diesem Beispiel zeigt sich die große Flexibilität des Kerngenoms und seiner regulatorischen Elemente.

Alle Proteine, deren Gene aus den Plastiden oder Mitochondrien in den Zellkern gewandert sind, und die daher im Cytoplasma synthetisiert werden, müssen von dort in die Plastiden und Mitochondrien importiert werden. Dazu ist zusätzliche Information für eine korrekte Adressierung an die Zielorganellen und den Durchtritt durch die Organellenhüllmembranen erforderlich. Die Struktur und Wirkungsweise solcher Adressen und Einschleusemechanismen werden im folgenden Kapitel behandelt.

\section{Weiterführende Literatur}

Arabidopsis Genome Initiative (2000) Analysis of the genome sequence of the flowering plant Arabidopsis thaliana. Nature 408: 796-815

Brennicke A, Grohmann L, Hiesel R, Knoop V, Schuster W (1993) The mitochondrial genome on its way to the nucleus: Different stages of gene transfer in higher plants. FEBS Lett 325: 140-145

Davis CC, Wardack KJ (2004) Host-to-parasite gene transfer in flowering plants: Phylogenetic evidence from Malpighiales. Science 305: 676-678

Lodish H, Berk A, Zipursky S, Lawrence S, Matsudaira P, Baltimore D, Darnell J (2001) Molekulare Zellbiologie. Spektrum, Heidelberg

Filipowicz W, Hohn T (eds) (1996) Post-transcriptional control of gene expression in plants. Kluwer, Dordrecht

Hagemann R (1999) Allgemeine Genetik. Spektrum, Heidelberg

Herrmann RG (1996) Eukaryotismus und seine Evolution. Nova Acta Leopoldina 42: 343-361

Knippers R (2006) Molekulare Genetik. Thieme, Stuttgart
Kidner CA, Martienssen RA (2005) The developmental role of microRNAs in plants. Curr Opin Plant Biol 8: 38-44

Lewin B (2009) Genes. Jones and Bartlett, Boston

Martin W, Embley TM (2004) Early evolution comes full circle. Nature 431: 134-136

Schmitz-Linneweber C, Small ID (2008) Pentatricopeptide repeat proteins: a socket set for organelle gene expression. Trends Plant Sci 13: 663-670

Seyffert, W (2003) Lehrbuch der Genetik. Spektrum, Heidelberg

Tielens AGM, Rotte C, van Hellemond JJ, Martin W (2002) Mitochondria as we don't know them. Trends Biochem 27: 564-570

Unseld M, Marienfeld JR, Brandt P, Brennicke A (1997) The mitochondrial genome of Arabidopsis thaliana contains 57 genes in 366,924 nucleotides. Nature Genet 15: 57-61

Weigel D, Glazebrook J (2002) Arabidopsis: A laboratory mannual. Cold Spring Harbor Laboratory Press, Cold Spring Harbor

Westhoff P, Jeske H, Jürgens G, Kloppstech K, Link G (1996) Molekulare Entwicklungsbiologie der Pflanzen. Thieme, Stuttgart

Wobus U, Borisjuk L, Panitz R, Manteuffel R, Bäumlein H, Wohlfahrt T, Heim U, Weber H, Miséra S, Weschke W (1995) Control of seed storage protein gene expression: New aspects on an old problem. J Plant Physiol 145: 592-599

Zehrmann A, van der Merwe JA, Verbitskiy D, Brennicke A, Takenaka M (2009) A DYW-domain containing PPR-protein is required for RNA editing at multiple sites in mitochondria of Arabidopsis thaliana. Plant Cell 21: 558-567

\section{In Abbildungen und Tabellen zitierte Literatur}

Carels N, Barakat A, Bernardi G (1995) Proc Natl Acad Sci USA 92: 11057-11060

Gallie DR (1996) In: Filipowicz W, Hohn T (eds) Post-transcriptional control of gene expression in plants. Kluwer, Dordrecht

Goldberg RB, Barker SJ, Perez-Grau L (1989) Cell 56: 149-160 Gruissem W, Barkan A, Deng XW, Stern D (1988) Trends Genet 4: $258-263$ 
Hajdukiewicz PTJ, Allison LA, Maliga P (1997) EMBO J 16: 4041-4048

Kadouri A, Atsmon D, Edelman M (1975) Proc Natl Acad Sci USA 72: 2260-2264

Kuhlmann M, Nellen W (2004) Biologie in unserer Zeit 34: $142-150$

Lea PJ, Leegood RC (1993) Plant biochemistry and molecular biology. Wiley, New York

Narayan RKJ, Rees H (1976) Chromosoma 54: 141-154
Nugent JM, Palmer JD (1991) Cell 66: 473-481

Rees H (1976) Trends Biochem Sci 1: N250-N251

Ronemus MJ, Galbiati M, Ticknor C, Chen J, Dellaporta SL (1996) Science 273: 654-657

Takahashi Y, Niwa Y, Machida Y, Nagata T (1990) Proc Natl Acad Sci USA 87: 8013-8016

Umesono K, Ozeki H (1987) Trends Genet 3: 281-287

Westhoff P, Jeske H, Jürgens G, Kloppstech K, Link G (eds) (1996) Molekulare Entwicklungsbiologie. Thieme, Stuttgart 